\title{
OUT OF THE CLOSET AND UP THE LADDER? DIVERSITY IN ONTARIO'S BIG LAW FIRMS
}

\author{
Asher Alkoby* \\ Pnina Alon-Shenker**
}

\begin{abstract}
While Canadian law generally provides protection against sexual orientation discrimination, and social acceptance is growing, there are some indications that LGBTQ lawyers face barriers relating to their sexual identity. Although more LGBTQ lawyers are now 'out at work', quantitative data is incomplete, and little is known about the actual experience of LGBTQ lawyers, who enter big firms in Ontario with the hope to advance through the ranks. This article begins to address this gap by providing qualitative analysis of the personal experience of LGBTQ lawyers entering the profession and the extent to which in-firm diversity initiatives shape their experience. Three main themes emerged from the interviews. First, racialized gay lawyers more consciously described their experiences at big law firms as negative and related them to their minority status. Second, the interviews offer insight into the ways in which gays and lesbians are forced to negotiate and perform their identity in a heteronormative workplace. Finally, the insights gleaned from the interviews suggest that the diversity programs devised by law firms may have helped diversify the lower ranks of law firms, but they seem to have failed to address the barriers that equity-seeking groups continue to face in retention and advancement through the ranks. The heteronormative organizational culture, as well as the promotion and compensation structures in firms continue to drive the composition of the leadership ranks and they arguably perpetuate homogeneity.
\end{abstract}

Malgré la protection généralement accordée en droit canadien à l'encontre de la discrimination fondée sur l'orientation sexuelle et l'évolution de la société à cet égard, certains indicateurs laissent croire que les avocats LGBTQ connaissent des obstacles liés à leur identité sexuelle. Bien que de plus en plus d'avocats LGBTQ exercent ouvertement leur profession aujourd'hui, les données quantitatives sont incomplètes et peu de renseignements sont connus au sujet de l'expérience que vivent ces avocats, qui entrent dans de grands cabinets de l'Ontario dans l'espoir de gravir les échelons. Dans cet article, les auteurs abordent cette question en présentant une analyse qualitative de l'expérience personnelle d'avocats $L G B T Q$ en début de carrière et des répercussions des initiatives internes en matière de diversité sur cette expérience. Trois grands thèmes ressortent des entrevues. D'abord, les avocats gays racialisés ont plus que les autres reconnu que l'expérience qu'ils avaient vécue dans de grands cabinets d'avocats avait été négative et ont attribué ce constat à leur statut de membres d'une minorité. En deuxième lieu, les

* Associate Professor, Department of Law \& Business, Ted Rogers School of Management, Ryerson, Canada.

** Associate Professor, Department of Law \& Business, Ted Rogers School of Management, Ryerson, Canada. This research project was funded by the Centre for Labour Management Relations, Ryerson University. The authors would like to thank Kira Domratchev, Annice Blair and Sara Wong for their excellent research assistance. An early version of this article was presented at The $15^{\text {th }}$ Jerusalem Conference in Canadian Studies 2016 Rethinking Diversity and Multiculturalism. The authors thank the conference participants for their insightful comments. 
entrevues donnent un aperçu des façons dont les lesbiennes et les gays sont forcés de négocier et d'affirmer leur identité dans un milieu de travail hétéronormatif. Enfin, il appert également des entrevues que les programmes de diversité conçus par les cabinets d'avocats ont peut-être favorisé la diversité au sein des cabinets d'avocats de petite taille, mais ils n'ont apparemment pas permis d'éliminer les obstacles auxquels se heurtent les membres des groupes à la recherche d'équité pour conserver leur poste et gravir les échelons. La culture hétéronormative de l'organisation ainsi que les structures de promotion et de rémunération des cabinets continuent à avoir une influence sur la répartition des postes de direction et ont probablement pour effet de perpétuer l’homogénéité.

\section{INTRODUCTION}

Ontario's legal profession has been grappling with its lack of diversity for a number of years now. The representation of women and racialized minorities in the profession has been the focus of the discussion so far. ${ }^{1}$ While women comprise over half of the Canadian population, ${ }^{2}$ and are now well represented among law school graduates (with more than $50 \%$ of those called to the Bar in Ontario), ${ }^{3}$ they often pursue careers outside of law firms, and are less likely to become partners when they do join a law firm. ${ }^{4}$ Similarly, the proportion of racialized lawyers in Ontario continues to increase (from $9 \%$ of the profession in 2001 to $18.6 \%$ in 2015). Yet they are more likely to be sole practitioners, in-house counsel or work for the government in comparison to non-racialized lawyers. ${ }^{5}$ They are also less likely to become law firm partners or hold other leadership positions. ${ }^{6}$

1 See e.g. Charles C Smith, "Who is Afraid of the Big Bad Social Constructionists? Or Shedding Light on the

Unpardonable Whiteness of the Canadian Legal Profession" (2008) 45 Alta L Rev 55; Wendy Cukier et al, DiverseCity Counts 3: A Snapshot of Diverse Leadership in the GTA (Toronto: Diversity Institute, Ryerson University, 2011), online: $<\mathrm{http}$ //www.lawinaction.ca/sites/default/files/page/attachments/DiversityCountsReport.pdf $>$; Beth Bilson, "A Dividend Diversity: The Impact of Diversity on Organizational Decision Making" (2011) 44 UBC L Rev 9; Jennifer Chow, "The Call to Diversify the Legal Profession (2011) 44 UBC L Rev 25; J Charlotte Ensminger, "Accessing Justice: The Legal Profession's Role in Serving the Public's Diverse Legal Needs" (2011) 44 UBC L Rev 71; Carman J Overholt, "Diversity and Professionalism in the Practice of Law" (2011) 44 UBC L Rev 91; Fiona M Kay, Stacey Alarie \& Jones Adjei, The Diversification of Career Paths in Law: Tracking Movement out of Private Practice among a Recent Two Decade Cohort of Law Graduates (A Report to the Law Society of Upper Canada, 2015), online:

$<\mathrm{http}$ //www.lsuc.on.ca/uploadedFiles/Equity_and_Diversity/Members2/Fiona_Kay_Diversification_report_Jan_2015\% 281\%29.pdf>; Kathleen Killin, "Will it ever be 50/50?: Diversity and Gender in the Law Firm and on Corporate Boards" (1 August 2015) Osgoode Legal Studies Research Paper No 25/2016, online:

$<$ http://papers.ssrn.com/sol3/papers.cfm?abstract_id=2730629>.

2 See Anne Milan, "Female Population in Statistics Canada, Women in Canada: Gender-based Statistical Report, $7^{\text {th }}$ edition, 30 March 2015, online: <http://www.statcan.gc.ca/pub/89-503-x/2015001/article/14152-eng.htm>.

3 See Law Society of Upper Canada, The Changing Face of the Legal Profession 2007-2012: Fact Sheet (2012), online: $<$ http://www.lsuc.on.ca/WorkArea/DownloadAsset.aspx?id=2147491913>.

4 See Michael Ornstein, The Changing Face of the Ontario Legal Profession, 1971-2001 (A Report to the Law Society of Upper Canada, 2004) [Ornstein, The Changing Face] at 26-27, online:

$<$ www.lsuc.on.ca/WorkArea/DownloadAsset.aspx?id=2147487138>; Michael Ornstein, Racialization and Gender of Lawyers in Ontario (A Report for the Law Society of Upper Canada, 2010) [Ornstein, Racialization] at 25, online: $<\mathrm{http} / /$ www.lsuc.on.ca/media/convapril10_ornstein.pdf>; Law Society of Upper Canada, Statistical Snapshot of Lawyers from the Lawyer Annual Report (LAR) 2015, online: <http://www.annualreport.lsuc.on.ca/2016/en/theprofessions/snapshot-lawyers.html> [LSUC, Snapshot].

5 Ornstein, The Changing Face, supra note 4 at 37.

6 Ornstein, Racialization, supra note 4 at 24; LSUC, Snapshot supra note 4; Cukier et al, supra note 1 at 30. 
The Law Society of Upper Canada [LSUC] has worked on several initiatives that aim to address both overt discrimination and implicit bias in the legal profession. These include, for example, the establishment of the Discrimination and Harassment Counsel [DHC] Program, ${ }^{7}$ the introduction of the Fair Hiring Practices Guidelines, ${ }^{8}$ and the creation of the Equity and Diversity Mentorship Program. ${ }^{9}$

Most significantly, in 2012, the LSUC created the Challenges Faced by Racialized Licensees Working Group (WG) with a mandate to identify challenges faced by racialized lawyers (and paralegals) in the practice of law, and consider strategies and best practices to address these challenges. A study commissioned by the WG attempted to identify challenges faced by racialized licensees relating to entry into and advancement in the legal profession. It involved a survey instrument as well as interviews and focus groups. ${ }^{10}$ The recommendations included in the WG's final report were approved by LSUC's Convocation on December 2, 2016. These recommendations aim to make the legal workplace in Ontario more inclusive by accelerating a cultural shift, measuring progress, education initiatives and the implementation of support systems. ${ }^{11}$ When debating these recommendations, the LSUC approved a motion to ensure that "the policies, procedures, measures and initiatives are extended as appropriate to all equity-seeking groups." 12 This allows for the consideration of challenges faced by gay, lesbian, bisexual, transgender and queer [LGBTQ] licensees as well. ${ }^{13}$

There are some indications that LGBTQ lawyers face barriers relating to their sexual identity, which would warrant the same type of response offered by the WG's recommendations. ${ }^{14}$ Canadian law generally provides protections against discrimination based on sexual orientation that are more advanced in comparison to other countries. Canadian society has also been relatively receptive to the idea of LGBTQ rights to equality. With the growing social acceptance, more LGBTQ lawyers are now 'out at work' and their résumés or social network profiles often reveal their sexual identity. As a result, LGBTQ lawyers are more visible in the workplace than they used to be. ${ }^{15}$ What does this mean for the ability of young lawyers to enter big firms and advance through the ranks? Available quantitative data is incomplete (for reasons we will explore below), and little is known about the actual experience of LGBTQ lawyers who enter big firms in Ontario with the hope to advance through the ranks. This article begins to address this gap by providing qualitative analysis of the experience of LGBTQ lawyers entering the profession.

7 Law Society of Upper Canada, Sexual Orientation and Gender Identity: Creating an Inclusive Work Environment - A Guide for Law Firms and Other Organizations (2014) [LSUC, Sexual Orientation] at 9, online:

$<\mathrm{http}: / /$ www.lsuc.on.ca/uploadedFiles/Equity_and_Diversity/Members2/Sexual_Orientation_Guide_November_2014.pd $\mathrm{f}>$.

8 Law Society of Upper Canada, Summary of Fair Hiring Practice Guidelines (2011), online: $<$ http://www.lsuc.on.ca/WorkArea/DownloadAsset.aspx?id=2147487145>.

9 Ibid.

10 David Kraft, John Willis \& Michael F Charles, Challenges Facing Racialized Licensees: Final Report (StartCom Strategic Communications, 11 March 2014) at 31-38, online: <http://www.stratcom.ca/wpcontent/uploads/manual/Racialized-Licensees_Full-Report.pdf>.

11 Law Society of Upper Canada Equity and Aboriginal Issues Committee, Report to Convocation December 2, 2016 , online:

$<$ http://www.lsuc.on.ca/uploadedFiles/For_the_Public/About_the_Law_Society/Convocation_Decisions/2016/Convocati on-Dec-2016-Equity-and-Aboriginal-Issues-Committee.pdf $>$ [LSÜC Committee, Report 2016].

12 LSUC, Public Minutes for Dec 2-16 Convocation, online: <https://www.lsuc.on.ca/Convocation-Dec-2016/>.

13 Some use a more inclusive abbreviation such LGBTQIA (which include Queer, Intersex and Asexual communities) and even LGBTTIQQ2SA (lesbian, gay, bisexual, transsexual, transgender, intersex, queer/questioning, two-spirited, and allies) (see LSUC, Sexual Orientation, supra note 7 at 8).

14 See the discussion below in Section III.

15 See e.g. James G. Leipold, "Stand and be Recognized: The Emergence of a Visible LGBT Lawyer Demographic" (20122013) 42 Sw L Rev 777. 
Sections II and III of this article provide the context for the discussion by considering the remarkable progress made on the legal protection and social acceptance of sexual minorities in Canada, and the available data on their representation in the legal profession. Section IV considers the steps big law firms have taken to make their organizations more diverse and inclusive. Over the past few years, large law firms have been actively seeking to attract LGBTQ lawyers by modifying their hiring practices and by fostering an inclusive work environment through support for employee groups, through the creation of mentorship programs and through the work of diversity committees. By speaking with gay and lesbian lawyers who work (or have worked) in big law firms, we wanted to learn about their personal experiences in these firms and the extent to which the in-firm initiatives shape these experiences. We discuss the results of these interviews in Section V.

While our sample size was relatively small (with 15 participants), it is the first exploratory study of the lived experiences of gay and lesbian lawyers in big Canadian firms, and the insights they offer are instructive. First, racialized gay lawyers more consciously described their experiences at big law firms as negative and related them to their minority status. This indicates that belonging to more than one stigmatized social category makes it doubly challenging for gay and lesbian lawyers to create meaningful relationships in a firm that would help them succeed and advance.

Second, the stories we heard offer insight into the ways in which gays and lesbians negotiate and perform their identity in a heteronormative workplace. Heteronormativity, the gender roles it assumes, and the stereotypes it reinforces, could have negative consequences for gay and lesbian lawyers who choose not to perform the role dictated by a heterosexual, patriarchal culture - that of the 'normal gay.'

Finally, the insights gleaned from the interviews suggest that the diversity programs devised by law firms may have helped diversify the lower ranks of law firms, but they seem to have failed to address the barriers that equity-seeking groups continue to face in retention and advancement through the ranks.

Section VI considers the diversity practices we heard about and evaluates their likelihood of success in light of the interview findings as well as what the available literature on workplace diversity tells us about what works and what does not work. Big law firms' responses to the diversity gap, we argue, may be viewed as the 'instrumentalization of diversity,' namely the advancement of a social cause for the purpose of gaining organizational presence and enhancing the reputation (or identity capital) of the firm. ${ }^{16}$ In other words, the signals big law firms have been sending to their relevant audiences (the regulator, prospective employees, and clients) have been successful in the sense that corporate clients who would like to see the diversity gap closing are kept at bay, and the firm becomes an attractive option for top junior gay and lesbian talent. The heteronormative organizational culture, as well as the promotion and compensation structures in law firms, however, continue to drive the composition of the leadership ranks and they arguably perpetuate homogeneity.

\section{LEGAL PROTECTION OF LGBTQ RIGHTS AND GROWING SOCIAL ACCEPTANCE}

In a relatively progressive Canadian legal environment, the past three decades have seen both a transformation in the legal protection of LGBTQ rights and broad social acceptance of LGBTQ individuals. ${ }^{17}$ In 1977, Québec was the first Canadian jurisdiction to prohibit sexual orientation

16 See Elizabeth Jane Ward, Respectably Queer: Diversity Culture in LGBTQ Organizations (Nashville: Vanderbilt University Press, 2008).

17 Compare to the U.S., where only 22 states and D.C. have laws prohibiting discrimination based on sexual orientation in the private sector, there is no federal law or Supreme Court decision banning such discrimination, leaving many LGBTQ unprotected. While the Seventh Circuit held that sexual orientation claims may be brought under the sex discrimination 
discrimination. ${ }^{18}$ Since then, each provincial jurisdiction has passed laws to prohibit workplace discrimination based on sexual orientation. ${ }^{19}$ In 1995, the Supreme Court held that sexual orientation constituted a prohibited ground of discrimination under s. 15 of the Canadian Charter of Rights and Freedoms, ${ }^{20}$ and in 1998 it forced Alberta to make sexual orientation a prohibited ground in that province. ${ }^{21}$ Recently, some jurisdictions have added protection on grounds of gender identity and gender expression. ${ }^{22}$ Canada was also one of the first countries to legally recognize same sex marriage, ${ }^{23}$ and other laws have been amended to reflect this recognition. Most recently, the federal government has announced that it plans to clear the criminal records of LGBTQ people convicted of consensual sexual activities. ${ }^{24}$

The legal protections for LGBTQ individuals reflect a broader trend toward a growing social acceptance of sexual minorities, both in Canada and globally. ${ }^{25}$ This trend is often explained through cohort analyses where less tolerant generations are replaced by more tolerant ones. ${ }^{26}$ This trend is also evident in the workplace. For example, according to a 2011 Angus Reid online survey, 93\% of LGBTQ respondents described their employers' overall attitude toward LGBTQ people in the workplace as 'tolerant' and $72 \%$ felt that attitudes in the workplace toward LGBTQ individuals have improved in recent years. ${ }^{27}$ Still, over a third experienced workplace discrimination and over a quarter are not 'out at work' as they fear the negative consequences. ${ }^{28}$ The next Section focuses on the legal profession and shows that,

provisions of Title VII of the Civil Rights Act of 1964, other courts have consistently ruled the opposite. See Hively v Ivy Tech Community College, No 15-1720 ( $7^{\text {th }}$ Cir, 4 April 2017); Evans v Georgia Reginal Hospital, No $15-15234$ (1 $1^{\text {th }}$ Cir 2017).

18 S. 10 of the Charter of Human Rights and Freedoms, CQLR c C-12.

19 See e.g. s 5 of Ontario Human Rights Code, RSO 1990, c H19 [OHRC].

20 Egan v Canada [1995] 2 SCR 513. See also John Fisher, "Outlaws or In-Laws? Success and Challenges in the Struggle for LGBT Equality" (2004) 49:4 McGill LJ 1183.

$21 \quad$ Vriend v Alberta [1998] 1 SCR 493.

22 In Ontario, gender identity and gender expression were added in 2012 (s. 5 of $O H R C$ ). At the federal level, Bill C-16 (received Royal Assent on June 19, 2017) was added to the Canadian Human Rights Act and the Criminal Code protection for gender identity and gender expression.

23 See the Civil Marriage Act, SC 2005, c 33, section 2.

24 John Ibbitson, “Canada's Swift Shift from Criminality to Acceptance of Homosexuality”, The Globe \& Mail (1 March 2016).

25 In Canada public acceptance of LGBTQ since 2007 has grown by 10\%. See Pew Research Center, "The Global Divide on Homosexuality: Greater Acceptance in More Secular and Affluent Countries" (4 June 2013), online:

$<$ http://www.pewglobal.org/2013/06/04/the-global-divide-on-homosexuality/>. See also Joanna Everitt \& Michael Camp, "In Versus Out: LGBT Politicians in Canada" (2014) 48:1 J Can Studies 226; Stacey L Sobel, "Culture Shifting at Warp Speed: How the Law, Public Engagement, and Will \& Grace led to Social Change for LGBT People" (2015) 89:1 St John's L Rev 143.

26 Pew Research Center, supra note 25. See also Alison G Keleher \& Eric RAN Smith, "Explaining the Growing Support for Gay and Lesbian Equality Since 1990" (2012) 59 J Homosexuality 1307; Ronit Dinovitzer, Law and Beyond: A National Study of Canadian Law Graduates (2015), online: UTORweb $<$ http://individual.utoronto.ca/dinovitzer/images/LABReport.pdf $>$.

27 Angus Reid Institute, "Most LGBT Working Canadians Experience Tolerance but Some Discrimination Persists" (15 November 2011), online: <http://angusreid.org/most-lgbt-working-canadians-experience-tolerance-but-somediscrimination-persists/>.

28 Ibid. See also Thomas Sasso \& Amy Ellard-Gray, In \& Out: Diverging Perspectives on LGBT Inclusion in the Workplace (Canadian Centre for Diversity and Inclusion, 2015) at 19-21, online: <http://www.ccdi.ca/wpcontent/uploads/2015/05/20150528-Report-LGBT-In-and-Out-Diverging-Perspectives-on-LGBT-Inclusion-in-theWorkplace-Final.pdf>; Greta Bauer et al, "We've Got Work to Do: Workplace Discrimination and Employment Challenges for Trans People in Ontario" (2011) 2:1 Trans PULSE e-Bulletin, online: <www.transpulseproject.ca>. In the U.S., see e.g. MV Lee Badgett et al, "Bias in the Workplace: Consistent Evidence of Sexual Orientation and Gender 
similarly, while protection is provided and social acceptance is increasing, LGBTQ lawyers experience discrimination and face unique challenges.

\section{AVAILABLE DATA ON LGBTQ LAWYERS IN ONTARIO}

The LSUC's Rules of Professional Conduct and the Paralegal Rules of Conduct prohibit discrimination and harassment in the legal workplace, including on the basis of sexual orientation. ${ }^{29}$ Under these rules, lawyers, paralegals and law firms have "a positive obligation to develop a work environment that promotes respect for the personal characteristics of all individuals affiliated with the legal profession." 30 And indeed, as legal protections and social acceptance are growing, LGBTQ lawyers have become more visible (or 'out') in the workplace, and their employers are increasingly aware of their obligation to foster an inclusive work environment.

There is some evidence, however, that LGBTQ lawyers in Canada continue to face challenges in the workplace. ${ }^{31}$ For example, according to the Law Society of Alberta, $88 \%$ of the gay, lesbian and bisexual lawyers and $68 \%$ of the heterosexual lawyers, who responded to a survey in 2004, believed that there was discrimination on the basis of sexual orientation in the legal profession. Further, $40 \%$ of the gay, lesbian and bisexual respondents had experienced discrimination in the five years prior to the survey. Discrimination took various forms including lack of promotion, poor work assignments, and dismissal. ${ }^{32}$ The Diversity and Harassment Counsel in Ontario reported that out of 586 discrimination and harassment complaints against lawyers and articling students between 2003 and 2012, 5\% were on the basis of sexual orientation. ${ }^{33}$ The LSUC Articling Task Force Consultation Report found that $13.6 \%$ of self-identified LGBTQ candidates could not find an articling position in 2011 (higher than the 10\% for the total candidates and slightly lower than the $15 \%$ for visible minorities). ${ }^{34}$

These findings do not provide a complete picture of substantive diversity in the legal profession. A more direct measure would consider the representation levels of LGBTQ lawyers in the profession, particularly in leadership positions. The LSUC has recently started to publish aggregate results of the demographic data collected through self-identification in the Lawyer Annual Report. In 2014, 2.9\% of the

Identity Discrimination 1998-2008" (2009) 84:2 Chicago-Kent L Rev 559; András Tilcsik, "Pride and Prejudice:

Employment Discrimination against Openly Gay Men in the United States” (2011) 117:2 American J Sociology 586.

29 Rule 6.3.1 of Rules of Professional Conduct (Toronto: Law Society of Upper Canada, November 1, 2000, as amended based on the Federation of Law Societies Model Code of Professional Conduct, effective October 1, 2014), online: $<$ http://www.lsuc.on.ca/lawyer-conduct-rules/>; Rule 2.03 of Paralegal Rules of Conduct (Toronto: Law Society of Upper Canada, May 29, 2007, as amended based on the Federation of Law Societies Model Code of Professional Conduct, effective October 1, 2014), online: <http://www.lsuc.on.ca/paralegal-conduct-rules/>.

30 LSUC, Sexual Orientation, supra note 7 at 5.

31 Ibid at 8. An online survey on sexual orientation and gender identity in the legal profession is currently conducted by Queen's University and the Canadian Bar Association. Results have yet to be released. See Audrey Kobayashi \& Kathleen Lahey, "Sexual Orientations and Gender Identities in the Legal Profession - Invisibility, Disclosure, and Equality", online: <http://law.queensu.ca/news/sogiSurvey>.

32 Merrill Cooper et al, Final Report on Equity and Diversity in Alberta's Legal Profession (Calgary: Law Society of Alberta, 2004).

33 Cynthia Peterson, 10 Year Summary Report of the Activities of the Discrimination and Harassment Counsel for the Law Society of Upper Canada: Summary of Data from January 1, 2003 to December 31, 2012 (Toronto: Law Society of Upper Canada, 2012), online: $<$ http://www.dhcounsel.on.ca/enca/Documents/pdf/Report\%20\%2810\%20year\%20summary\%20of\%202003-2012\%29\%20English.pdf>.

34 Law Society of Upper Canada, Articling Task Force Consultation Report (Toronto: Law Society of Upper Canada, 2011) at Appendix 5, page 6, online: <http://www.lsuc.on.ca/articling-task-force-consultation-report/>. 
lawyers, who answered the sexual orientation question, identified themselves as LGBTQ. ${ }^{35}$ It went slightly up to $3.1 \%$ in the following annual report of $2015 .^{36}$

It is difficult to tell whether 3.1\% represents a small proportion of the profession in Ontario, when compared to the representation of LGBTQ individuals in the general population. There is no official data available, as sexual orientation and gender identity are not included on the census form Canadians fill out. According to the Canadian Community Health Survey, 1.7\% of Canadians aged 18 to 59 reported in 2014 that they were gay or lesbian and $1.3 \%$ that they were bisexual. ${ }^{37}$ But other reports provide higher estimates ranging from $6 \%$ to $9 \%$ and sometimes as high as $11 \%$. It is also reported that almost half of the LGBTQ population in Canada is located in Ontario. ${ }^{38}$ Furthermore, upon examining the distribution across all ranks, it is striking to see how only a few of the self-identified LGBTQ lawyers are in senior positions in law firms. LGBTQ lawyers in Ontario are about two to three times more likely to work in education, legal clinics or the government than non-LGBTQ lawyers, and they are less likely to be law firm partners. ${ }^{39}$ This annual reporting is done at the aggregate level, although recent developments suggest that in the coming years, these reports may provide a more detailed analysis of firms' diversity profiles. ${ }^{40}$

Data available in the U.S. shows that while more positions are held today by LGBTQ lawyers, these rarely include positions of power and leadership. In 2016, 2.48\% of lawyers reported in the National Association for Law Placement [NALP] Directory of Legal Employers were openly LGBTQ. Representation rates have been low but slightly increased over the years; the numbers have more than doubled since 2002 (from just over 1,100 to 2,431). Yet, most of the increase has occurred among associates. While among associates 3.24\% were LGBTQ, among partners it was only $1.89 \%$ in 2016 . $^{41}$ Similar to the LSUC report on Ontario lawyers, recent LGBTQ graduates in the U.S. are reportedly much less likely to take a job in private practice and much more likely to take a job with a public interest organization. ${ }^{42}$ Some have suggested that in anticipation of discrimination, LGBTQ individuals have lower initial career expectations, espouse more altruistic work values compared to heterosexual individuals, and make career choices based on these values. ${ }^{43}$

35 While lawyers can skip the self-identification question, the response rate for sexual orientation was very high (82.1\%). Law Society of Upper Canada, Statistical Snapshot of Lawyers from the Lawyer Annual Report (LAR) 2014, online: $<$ http://www.annualreport.lsuc.on.ca/2015/en/the-professions/snapshot-lawyers.html .

36 LSUC, Snapshot, supra note 4. Response rate for sexual orientation was very high (81.9\%).

37 Statistics Canada, "Same-Sex Couples and Sexual Orientation by the Numbers", The Daily (2015), online: $<$ http://www.statcan.gc.ca/eng/dai/smr08/2015/smr08_203_2015\#a3>.

38 See Evra Taylor, "Is Canada's Lesbian, Gay, Bisexual and Transgender Community Worth Pursuing?" (9 July 2012), online: <http://www.marketingmag.ca/wp-content/uploads/2012/06/LastQ_LGBT_0612.jpg>.

39 In 2015, 9.6\% of LGBTQ were law firm partners compared to $16.6 \%$ of non-LGBTQ, 3.6\% were in legal clinic compared to $1.2 \%, 22.4 \%$ were in government compared to $13.1 \%, 2.9 \%$ were in education compared to $1.3 \%$. See LSUC, Snapshot, supra note 4.

40 See LSUC Committee, Report 2016, supra note 11 at 91 discussed in the introduction above.

41 See National Association for Law Placement, "LGBT Representation among Lawyers in 2016", NALP Bulletin (January 2017), online: <http://www.nalp.org/0117research>. See also Elizabeth Chambliss, "IILP Review 2014: The State of Diversity and Inclusion in the Legal Profession. Institute for Inclusion in the Legal Profession" (2014), online: $<$ http://www.theiilp.com/Resources/Documents/IILP_2014_Demographic\%20Summary.pdf>; American Bar Association/SOGI Commission, Goal III Report for 2014-2015 Seventh Annual Review of the Status of Lesbian, Gay, Bisexual, and Transgender Participation at the American Bar Association (2015), online:

$<\mathrm{https} / / /$ www.americanbar.org/content/dam/aba/administrative/racial_ethnic_diversity/2015GoallII.authcheckdam.pdf $>$.

42 National Association for Law Placement, "New Research on Employment Outcomes for Lesbian, Gay, and Bisexual Graduates", NALP Bulletin (November 2015), online: <http://www.nalp.org/1115research>.

43 Eddy SW Ng, Linda Schweitzer \& Sean T. Lyons, "Anticipated Discrimination and a Career Choice in Nonprofit: A Study of Early Career Lesbian, Gay, Bisexual, Transgendered (LGBT) Job Seekers” (2012) 32:4 Rev Public Personnel Admin 332. 
One of the main reasons to publish the data was to spur change. ${ }^{44}$ Whether the publication of data in the U.S. has been effective in terms of promoting more diversity among firms that did not perform well in previous reports is debatable. Although the NALP has been publishing data 1993, persons of colour, for example, are still significantly underrepresented among lawyers and even more so among partners. The progress made in the past two decades has not been significant. ${ }^{45}$ The LSUC seems to agree that "transparency about firm representation assists in increasing representation within firms." 46 Yet the argument often heard is that the LSUC cannot directly regulate firms or other legal organizations and therefore cannot require mandatory reporting. ${ }^{47}$ Several organizations, including the Canadian Bar Association and the Ontario Human Rights Commission, have tried to encourage law firms to measure their diversity and collect data on their demographics, with limited success. ${ }^{48}$ The Canadian Bar Association has been working with the Canadian Institute for Diversity and Inclusion on tracking the numbers of equity-seeking groups in law firms across Canada (Diversity by Numbers: The Legal Profession). ${ }^{49}$ They have finally released their first report in 2016, yet like the reports of the LSUC, it only provides aggregate results. ${ }^{50}$

When Canadian law firms choose to collect demographic data, they do so internally and do not share the results. ${ }^{51}$ Even when they partner with external organizations, the information remains confidential. For example, some firms have partnered with Pride at Work Canada and participate in its LGBT Inclusion Index, which was established in 2013. This index is an online benchmarking tool, which helps organizations (including law firms) to review and assess their workplace practices and policies and make their workplaces more inclusive to LGBTQ employees. Each company makes a confidential submission and receives individual comprehensive feedback and strategy support based on its results. ${ }^{52}$ While the index may provide an external assessment and support for companies wishing to improve their

44 See e.g. the recent statement of NALP Executive Director on recent findings: "These national benchmark data are helpful in highlighting the overall progress, or lack thereof, in achieving greater diversity among the lawyers working in U.S. law firms..." National Association for Law Placement, "2016 NALP Report on Diversity in U.S. Law Firms: Press Release" (January 4, 2017), online:

$<$ http://www.nalp.org/uploads/2016NALPReportonDiversityinUSLawFirmsPressRelease.pdf $>$.

45 See e.g. Veronica Root, "Retaining Color" (2013) 47 U Mich JL Ref 575. But see Sabrina Lyon \& Lorne Sossin, "Data and Diversity in the Canadian Justice Community" (2014) $11 \mathrm{JL} \&$ Equal 85 at 101, 117 (collection of demographic data by the NALP contributed to increase in representation rates of LGBTQ lawyers in the U.S.).

46 Law Society of Upper Canada, Developing Strategies for Change: Addressing Challenges Faced by Racialized Licensees (2012) at 26, online:

$<$ https://www.lsuc.on.ca/uploadedFiles/Equity_and_Diversity/Members/Challenges_for_Racialized_Licensees/Cons ultation_Paper_Offical(12).pdf $>$.

47 Ibid at 30. Convocation has approved in February 2014 the development of a proposed framework for the regulation of firms (ibid at 38). For a discussion of how entity regulation and diversity reporting are linked, see Alex Robinson, "Entity Regulation Encouraged to Boost Diversity" Law Times (25 September 25 2017), online:

$<$ http://www.lawtimesnews.com/author/alex-robinson/entity-regulation-encouraged-to-boost-diversity-13708/>.

48 Developing Strategies for Change, supra note 46 at 29.

49 Canadian Centre for Diversity and Inclusion, Diversity by the Numbers: The Legal Profession, online: $<$ http://www.ccdi.ca/dbtn-legal-sector/>.

50 The first report does not cover sexual orientation nor provides data on a firm-by-firm basis. It does reveal that both women and racialized minorities are underrepresented overall and in high-ranking roles. See Canadian Centre for Diversity and Inclusion, Diversity by the Numbers: The Legal Profession (30 November 2016), online:

$<$ http://www.ccdi.ca/attachments/DBTN_TLP_2016.pdfs.

51 See e.g. Christopher Guly, "Diversity Still a Challenge for Law Firms" (1 September 2011), online: $<$ http:/diversityintheworkplace.ca/newsletters/sept_2011/diversity-in-the-workplace-article-1-sept2011.php>.

52 Pride at Work Canada, "LGBT Workplace Inclusion Index", online: < http://prideatwork.ca/programs/lgbt-workplaceinclusion-index/>. 
performance, the score and results of each company remain confidential. The reluctance to collect and publish more specific data could be due to concerns about manipulating the numbers and the impact of blaming and shaming on law firms' reputation. ${ }^{53}$ But as Lyon and Sossin argue, data collection and publication may be a crucial step toward the establishment of better recruitment and retention practices and strategies. ${ }^{54}$

\section{DIVERSITY PRACTICES IN BIG LAW FIRMS}

The limited data available reviewed above suggests that LGBTQ individuals may be underrepresented in the Ontario legal profession, and that they are less likely to advance to leadership positons in law firms. To understand the nature of the barriers that equity-seeking groups face in big firms, it is useful to consider what efforts are made by law firms to diversify their workforce, particularly through hiring and retention practices and their impact on individuals who may not fit a particular mold.

While discrimination is commonly viewed as wrongful and forbidden, diversity tends to raise more controversy. Canadian employers, big law firms included, understand that it is unlawful to refuse to hire or promote a qualified candidate on prohibited grounds. More controversial is the idea that employers have a responsibility to actively pursue measures that would result in a diverse workforce. ${ }^{55}$ In this view, it is not enough to prohibit the intentional conduct of excluding members of a protected group, thereby providing equal opportunity to succeed. Employers who are truly committed to substantive diversity must also focus on the prevailing conditions, which prevent the hiring, retention and advancement of individuals from underrepresented groups. ${ }^{56}$

At first glance, it seems that most large law firms in Canada have embraced a progressive view of diversity. Many declare their deep commitment to equity issues on their websites. They also often take pride in their diverse and inclusive environment and their engagement in numerous diversity initiatives and events. Most large firms explicitly refer to the LGBTQ community when discussing diversity. Many have established diversity committees, affinity groups, and partner with external diversity-related organizations. Most big firms also offer special diversity training to their workers, boast about progressive parental benefits policies, and offer mentoring programs for junior lawyers. ${ }^{57}$

In addition to attracting a diverse and talented workforce, these signals also serve as a response to demands from major corporate clients that firms engage in activities that promote diversity. ${ }^{58}$ Most notably, several years ago a group of general counsel in some of Canada's largest companies came together to promote diversity in the legal profession. ${ }^{59}$ Representing some of the country's largest companies, Legal Leaders for Diversity and Inclusion [LLD] declared their willingness to lead the charge

53 Lyon \& Sossin, supra note at 45 at 109-10.

$54 \quad$ Ibid at 107, 116-23.

55 See Eli Wald, “A Primer on Diversity, Discrimination, and Equality in the Legal Profession or Who is Responsible for Pursuing Diversity and Why” (2011) 24 Geo J Leg Ethics 1079 at 1109-10.

56 Ibid at 1142.

57 This information can be found on the websites of the leading law firms listed in Lexpert Directory, "Canada's Largest Law Firms", online: <http://www.lexpert.ca/500/canadas-largest-law-firms/>.

58 See Jennifer Brown, "Half of Canadian GC's consider Diversity when Hiring External Law Firms: Poll”, Canadian Lawyer (5 June 2012), online: < http://www.canadianlawyermag.com/legalfeeds/893/half-of-canadian-gcs-considerdiversity-when-hiring-external-law-firms-poll.html>. In the U.S., see Christopher J. Whelan \& Neta Ziv, "Law Firm Ethics in the Shadow of Corporate Social Responsibility" (2013) 26:1 Geo J. Leg Ethics 153.

59 Legal Leaders for Diversity and Inclusion (LLD) is a group of Canadian General Counsel which aims at creating a more inclusive legal profession and supporting diversity initiatives. See: online:

$<\mathrm{http}$ ://legalleadersfordiversity.com/>. 
by working with big firms to diversify their ranks. Big firms were listening because the LLD network represents clients that have a major impact on the legal services they provide.

In response to pressures by the LLD to tackle diversity issues, sixteen of the largest law firms in Canada formed in 2013 the Law Firm Diversity and Inclusion Network (LFDIN) and signed the Statement of Principles. These law firms agreed, among other things, to share ideas on how to promote diversity, to work with the LLD and to evaluate their own efforts to diversify. ${ }^{60}$ Since then, more law firms have signed the Statement. ${ }^{61}$ And an increasing number of firms now have diversity committees, which had initially focused on gender issues and gradually expanded to other equity seeking groups such as racialized minorities, people with disabilities, and more.

A review of law firm management practices based on publicly available information, however, suggests that these initiatives have largely failed to shift the conversation from general efforts to increase diversity appearance, specifically at the entry-level, to tackling challenges to substantive diversity across all ranks in a meaningful way. In an effort to recruit and retain the best and brightest, law firms claim to base their hiring decisions on merit, regardless of any personal characteristics. ${ }^{62}$ But this insistence on evaluating lawyers on the basis of their individual merit, what Pearce et al termed "difference blindness standards", poses a significant barrier to substantive diversity. ${ }^{63}$ It may help reduce intentional discrimination, but not implicit and institutional bias, because it creates the illusion that lawyers are accountable to neutral standards and that success or failure depends on the individual rather than on structural constraints. ${ }^{64}$ As Pearce et al argue, "the work of lawyers, like that of all workers, is grounded in relationships;" and therefore law firms should not overemphasize individual outcomes "without paying attention to the surrounding interactional and institutional processes that produce them." 65 That is, it is not enough to remove explicit barriers by prohibiting comments or conduct which intentionally exclude equity-seeking groups, it is also crucial to examine the prevailing conditions, practices, and policies which inhibit their entry into, and participation in, the organization. ${ }^{66}$

Consider the hiring practice of law students, for example. The law firm recruitment cycle in Ontario typically begins with applications for a summer job for students. A successful summer job at the end of second year in a big law firm often leads to an articling position at the end of third year, and an opportunity to be hired as an associate upon completion of articles. In Ontario, the LSUC developed extensive procedures that govern the recruitment of students for summer positions through on-campus interviews [OCIs]. ${ }^{67}$ Interviews at each stage of this process do not attempt to assess knowledge or skills; they tend to be conversational and casual, for the purpose of determining whether the candidate would be 'a good

60 “Measuring Up on Diversity in the Legal Profession", LEXPERT (1 July 2014), online:

$<\mathrm{http} / /$ www.lexpert.ca/article/measuring-up-on-diversity-in-the-legal-profession/?p=\%7C273\&sitecode=DIR $>$.

61 See Statement online: Cox and Palmer Law

$<\mathrm{http} / / /$ www.coxandpalmerlaw.com/site/media/coxandpalmer/Law_Firm_Diversity_Network_Feb_2015.pdf $>$.

62 Guly, supra note 51; Russell G. Pearce, Eli Wald \& Swethaa S. Ballakrishnen, "Difference Blindness vs. Bias

Awareness: Why Law Firms with the Best of Intentions Have Failed to Create Diverse Partnerships" (2015) 83 Fordham

L Rev 2407.

63 Pearce et al, ibid.

$64 \quad$ Ibid at 2412-13, 2434.

$65 \quad$ Ibid at 2413.

66 See also William D. Henderson, "Solving the Legal Profession's Diversity Problem" (2016) Indiana Legal Studies Research Paper No. 335 (February 2016) PD Quarterly 23, online:

$<$ http://papers.ssrn.com/sol3/Papers.cfm?abstract_id=2742436> (hiring, work allocation, and lawyer development systems rooted in tradition and past practice are the main reason for lack of diversity in law firms in the U.S.).

67 See 2018 Toronto Summer Student Recruitment Procedures, online:

$<$ https://www.lsuc.on.ca/licensingprocess.aspx?id=2147500218>. 
fit' ${ }^{68}$ Candidates meet with different lawyers at the firm, are interviewed by a student hiring committee, and get to mingle with others in various settings, including sport bars or restaurants. As Gray puts it, "[s]electing the students with the best marks or résumés is not enough: Confidence, poise, and the ability to fit in with a firm's culture are just as important to success." 69

One law student described this process as an "idiosyncratic game of cloak and dagger, and a "make or break' moment for those aspiring to a career in big law." 70 He conducted a survey of his class (to which two thirds responded) and found that the majority of the students found the process very stressful. Of the students who reportedly received at least one offer from a big law firm, zero were gay or lesbian candidates. In his view, the problem lies in the search for good 'fit' with the firm culture which is prone to unconscious biases. ${ }^{71}$ Some additional insight into recruitment practices was offered by our research participants, as we discuss later in this article. ${ }^{72}$

Extensive empirical studies have shown that subtle and unconscious bias in the workplace is pervasive and it can significantly influence decision-making processes. ${ }^{73}$ Since it is unconscious, even wellintentioned people are prone to discriminate against others in the workplace. ${ }^{74}$ Law firms, as shown in the American context, are not immune to implicit bias concerns. Implicit bias is often embedded in their daily practices, policies and corporate culture. Despite their good intentions and general commitment to equality and diversity, law firm partners, who are still mostly white heterosexual men, often bring their biases to their workplace and feel most comfortable working with and mentoring people who are most like them, leaving others with less opportunities to develop the skills and relationships required to become partners. ${ }^{75}$

68 See Michael Motala, "Big Law's Hiring Emphasis on 'Fit' Tips the Balance against LGBT Candidates", The Globe \& Mail (4 February 2016), online:

$<$ http://www.theglobeandmail.com/report-on-business/rob-commentary/big-laws-hiring-emphasis-on-fit-tips-thebalance-against-lgbt-candidates/article28554340/>; Jeff Gray, "Battle for Talent: 'Speed Dating' for Success on Bay Street", The Globe \& Mail (20 December 2010), online: <http://www.theglobeandmail.com/report-on-business/industrynews/the-law-page/speed-dating-for-success-on-bay-street/article1320733/?page=all $>$.

69 Gray, ibid.

70 Motala, supra note 68.

71 Ibid.

72 The issue of "fit" was also identified as a significant barrier in the context of racialized lawyers both in the hiring process and in opportunities for advancement. See Developing Strategies for Change, supra note 46 at 12-13. See also Lauren A Rivera, Pedigree: How Elite Students Get Elite Jobs (Princeton: Princeton University Press, 2015), who investigated the hiring process in U.S. law firms (among other "highest-paying entry-level jobs") and documented the numerous ways in which "criteria" and "metrics" were used to filter students based on their parents' socioeconomic status.

73 See e.g. Irene V Blair, "The Malleability of Automatic Stereotypes and Prejudice" (2002) 6 Personality \& Soc Pyschol Rev 242; Nilanjana Dasgupta, "Implicit Ingroup Favoritism, Outgroup Favoritism, and their Behavioral Manifestations" (2004) 17 Soc Just Res 143.

74 See e.g. Linda H Krieger, "The Content of Our Categories: A Cognitive Bias Approach to Discrimination and Equal Employment Opportunity" (1995) 47 Stan L Rev 1161; Susan Sturm, "Second Generation Employment Discrimination: A Structural Approach" (2001) 101:3 Colum L Rev 458; Melissa Hart, "Subjective Decision Making and Unconscious Discrimination" (2005) 56 Ala L Rev 741; Christine Jolls \& Cass R Sunstein, "The Law of Implicit Bias" (2006) 94 Cal L Rev 969; Anthony Greenwalk \& Linda H Krieger, "Implicit Bias: Scientific Foundations" (2006) 94 Cal L Rev 945; Samuel R. Bagenstos, "Implicit Bias, 'Science', and Antidiscrimination Law" (2007) 1 Harv L \& Pol'y Rev 477; David L Faigman, Nilanjana Dasgupta \& Cecilia L Ridgeway, "A Matter of Fit: The Law of Discrimination and the Science of Implicit Bias" (2007-2008) 59 Hastings LJ 1389.

75 See e.g. Pearce et al, supra note 62; Deborah L Rhode, "Foreword: Diversity in the Legal Profession: A Comparative Perspective" (2015) 3 Fordham L Rev 2241; Nicole Negowetti, "Implicit Bias and the Legal Profession's 'Diversity Crisis': A Call for Self-Reflection" (2015) 15 Nevada LJ 431. Specifically on advancement and retention issues of racialized minorities see Monique R Payne-Pikus, John Hagan \& Robert L Nelson, "Experiencing Discrimination: Race and Retention in America's Largest Law Firms" (2010) 44:3-4 Law \& Soc'y Rev 553 (partner contact and mentoring are important in tackling racial differences in lawyer retention); Eric Chung et al, A Portrait of Asian Americans in the Law 
The case of sexual minorities is even more complex and evasive than that of other marginalized groups, as issues such as disclosure, identity and classification pose unique challenges. ${ }^{76}$ For example, a recent study by the Canadian Centre for Diversity and Inclusion, which included an online survey of individuals (including heterosexual) about the workplace experience of LGBTQ across Canada, found that heterosexual respondents did not understand the significance of being 'out at work', perhaps because they are already inadvertently out with their identity as they wear a wedding ring or have family photos on their desk and their identity is considered the norm in our society. By contrast, for LGBTQ respondents, disclosure at work is an important matter but is much more challenging. If the workplace environment is not inclusive, they might not feel comfortable disclosing important aspects of their identity. ${ }^{77}$

Unfortunately, there has been very little discussion on how to enhance LGBTQ inclusion in the legal profession in Canada. In Ontario, the LSUC has recently issued a Guide recommending that law firms adopt a variety of policies and procedures to eradicate LGBTQ discrimination and enhance diversity. These include, for example, workplace policies and practices relating to washrooms, dress code, name change, medical and leave benefits and privacy and confidentiality. ${ }^{78}$ The LSUC has also worked on several initiatives to promote diversity in the workplace, more generally, which may have impact on LGBTQ issues. ${ }^{79}$

It is yet unknown to what extent these policies are being used by law firms and whether they are effective. Much of the research conducted on American corporations has not found diversity training and other diversity initiatives to be very effective, unless they included some form of structural and systemic changes in the organization's approach. ${ }^{80}$

As noted above, the practice of hiring law students (which is a significant, if not the sole entryway of future junior lawyers into big firms) raises some concerns regarding structural barriers that could disproportionally impact candidates who may not fit a particular mold. What we know about the pervasiveness of bias and the limited effectiveness of training to reduce it suggests that these barriers may continue to impact the experience of junior lawyers who successfully entered the firm.

While hiring practices are somewhat transparent, much less is known about the practices relating to advancement within firms. Information on retention and promotion practices is not publically available

(Yale Law School, National Asian Pacific American Bar Association, 2017), online:

$<$ https://www.apaportraitproject.org/> (Asian Americans are now recruited into law firms but significantly underrepresented among partners, mainly due to implicit bias issues).

76 See e.g. LA Boso, “Acting Gay, Acting Straight: Sexual Orientation Stereotyping” (2016) 83 Tenn L Rev 575.

77 Sasso \& Ellard-Gray, supra note 28 at 16-17. See also Kevin G Alderson, The Corporate Closet: Career Challenges of Gay and Lesbian Individuals (Paper delivered at the Annual NATCON Convention, 2003), online:

$<$ http://eric.ed.gov/?id=ED481087>; Joshua C Collins \& Jamie L Callahan, "Risky Business: Gay Identity Disclosure in a Masculinized Industry" (2012) 15:4 Human Resources Development International 455.

78 LSUC, Sexual Orientation, supra note 7 at 20.

79 See text accompanying supra notes 7-9.

80 See e.g. Steve Kolowich, "Diversity Training is in Demand" (2015) 62:13 The Chronicle of Higher Education A6 (training programs on racial diversity may change how people think about racial differences but cannot change their real attitudes); Tessa L Dover, Brenda Major \& Cheryl R Kaiser, "Diversity Policies Rarely Make Companies Fairer, and They Feel Threatening to White Men" (4 January 2016) Harvard Business Rev (diversity initiatives did not convince minorities that companies would treat them more fairly); Joan F Marques, "Colorful Window Dressing: A Critical Review on Workplace Diversity in Three Major American Corporations" (2010) 21:4 Human Resource Development Q 435 (many American corporations are going out of their way to post diversity statements on their websites and to collect diversity-based awards from numerous minority-promoting organizations, but they are not actually so diverse in terms of their demographic composition); Alana Conner Snibbe, "Diversity Training Doesn't Work" (2007) 5:1 Stanford Social Innovation Rev 15 (diversity training might not be effective if it does not include a more systemic and structural view on discrimination). 
and even less is known about the impact of big firms' organizational culture on law students, articling students and junior associates hoping to advance within the firm. The research commissioned by LSUC offered some insight into the experiences of racialized licensees in the profession. It documented challenges reported by racialized lawyers in three areas. The first was discrimination and stereotypes, specifically the assumption by legal professionals that racialized lawyers are less competent, skilled or effective in their work. Almost half of the racialized respondents felt that they had to prove themselves competent at work more than non-racialized colleagues. The second concern raised relates to cultural difference, and the sense that the quest for the 'best fit' for a job often translates to non-racialized identity. Thirdly, while respondents acknowledged that most firms have formal mentoring programs, they indicated that more informal, organically developed mentoring relationships are much more crucial for the success of junior lawyers in firms, and racialized lawyers felt that they are less likely to have access to advice and guidance from senior colleagues than non-racialized colleagues. ${ }^{81}$

The perspective of LGBTQ lawyers has not been documented in the same way, and we were interested to learn about the impact sexual orientation and sexual identity may have on the lived experiences of lawyers in big firms. Against the social and legal backdrop described earlier, where growing protection and acceptance of sexual minorities is evident, we wanted to hear from individuals who have worked in big firms over the past ten years, in order to understand whether from their perspective, there are barriers to entry and advancement that are unique to LGBTQ lawyers. The insights they offered are discussed in the next Section.

\section{THE EXPERIENCE OF GAY AND LESBIAN LAWYERS IN BIG FIRMS}

Our data derives from research involving fifteen gay and lesbian lawyers who work (or have worked) in twelve of the largest law firms in Ontario (all have 100 or more lawyers employed). ${ }^{82}$ The Canadian Bar Association's interest group SOGIC (Sexual Orientation and Gender Identity Community) was the first point of contact in our recruitment efforts. ${ }^{83}$ After hearing from several of their members, we used snowball sampling to increase the number of participants. We also contacted diversity committees in various big law firms, as well as the organization Pride at Work Canada and similarly asked them to circulate our request to participate through their networks.

The fifteen lawyers included in this study represent a broad spectrum of experiences and backgrounds. Their level of experience ranges from two years to several decades, with eight who work (or have worked) as associates, and seven who are currently partners at a big firm. Their areas of practice are diverse, and some continue to work in big firms while others have left their firms, for various reasons. Thirteen of them self-identified as gay men, and two as lesbian women. We were unable to find participants from other members of the LGBTQ community. Therefore, while the insights offered in our interview findings have relevance to all sexual minorities (and perhaps members of other equity-seeking groups more broadly), they are limited to the experience of gay and lesbian lawyers. The discussion that follows will thus refer specifically to these identity groups rather than the broader acronym.

The interviews began with an invitation to the participants to describe their professional journey, the process of applying for their first law job, and their experience in the firm. In follow up questions, we tried

81 Kraft, Willis \& Charles, supra note 10 at 10-16; LSUC Committee, Report 2016, supra note 11 at 103-04.

82 We consider them "Ontario firms" for the purpose of this article even though they are all national firms. While the observations made by participants may apply to firm practices across its offices, their lived experiences are limited to the Toronto office of each firm.

83 On SOGIC, see: online: <http://cba-mb.ca/Sections/SOGIC $>$. 
to explore together with participants their understanding of the firm culture, and the workplace sensitivities toward sexual minorities. We specifically wanted to know whether they disclose their sexual identity at work, whether they experienced any challenges as gays and lesbians, and if they believe sexual identity can impede a lawyer's success in big firms. We also asked them what their firm is currently doing to enhance LGBTQ diversity, whether they find these measures effective and what in their view can be done to enhance the diversity of firms. To protect participants' privacy, the discussion below uses pseudonyms and the transcripts are coded for confidentiality purposes.

While all participants thought that this study is very important, the majority began by stating that in their view, being gay or lesbian on Bay Street (where many Toronto big firms are located) today is a "nonissue." They described their experience as very good and they thought that their sexuality had no material impact on their careers ("I was lucky" or "fortunate" were phrases we heard often). ${ }^{84}$ The narrative of coming out to colleagues in the firm was also largely positive, where initial anxiety was followed by surprise at how accepting or indifferent were the reactions of supervisors or colleagues ("the biggest yawn"). ${ }^{85}$

Research suggests that being out at work is very important for LGBTQ individuals, and most of the lawyers we spoke with agreed with this observation. ${ }^{86}$ The act of coming out was an important aspect of our participants' lived experiences in their firms. ${ }^{87}$ They explained that this is especially important in large law firms where lawyers work long hours in close collaboration with colleagues. ${ }^{88}$ Some participants described coming out as "liberating", ${ }^{89}$ and the feeling of working in such a demanding environment without being able to speak freely as "suffocating." 90 Some expressed a concern that the inability to talk freely might have the potential to negatively affect the performance of LGBTQ lawyers and their capacity to develop personal relationships at work, which are crucial for their success. ${ }^{91}$

While observing that large law firms are by and large conservative environments, some participants also viewed law firms as a relatively good place for gay and lesbian lawyers. ${ }^{92}$ Several participants shared stories about an overall inclusive environment at the firm, where they felt comfortable having photos of their partners and children displayed in their office, for example, or bringing spouses to work events. ${ }^{93}$ They generally felt that there is more social acceptance today than in the past, especially in a diverse city like Toronto, ${ }^{94}$ and that over the past two decades, students applying for law firm positions have been flagging their sexual identity explicitly on their resumes. Some candidates even asked related questions on the work environment during their job interviews. ${ }^{95}$

84 R1, pp 2-3, 5; R3, p 12; R5, pp 17-18; R6, p 3; R7, pp 4, 10; R9, p 11; R10, p 13; R12, p 6; R13, p 2.

85 R1, pp 3-4; and also, R6, p 3; R8, p 24; R11, p 3; R13, pp 3-4.

86 See text accompanying supra note 77 . While the majority of participants in this study agreed that being out at work is important, several believed that if a lawyer does excellent work, discretion would not affect his or her promotion. See R3, p 12; R5, p 15; R7, p 8 .

87 R4, pp 4-5; R5, pp 17-18; R6, p 10; R8, p 3; R10, p 4; R12, p 5; R14, p 6; R15, pp 3-4.

$88 \quad$ R5, p 15; R7, p 8; R8, p 8; R9, p 17; R12, p 6.

$89 \quad \mathrm{R} 1, \mathrm{p} 3 ; \mathrm{R} 4, \mathrm{p} 20 ; \mathrm{R} 12, \mathrm{pp} \mathrm{4,} 6$.

$90 \mathrm{R} 8, \mathrm{p} 24$.

$91 \quad \mathrm{R} 3, \mathrm{p} 12, \mathrm{R} 5, \mathrm{p} 15 ; \mathrm{R} 9, \mathrm{p} 17 ; \mathrm{R} 14, \mathrm{p} 7$.

92 R1, p 12; R6, p 6; R8, p 6; R9, p 5; R10, p 25; R14, pp 3,15; R15, p 3.

$93 \quad \mathrm{R} 6, \mathrm{pp} 5-6 ; \mathrm{R} 9, \mathrm{pp} 10-11 ; \mathrm{R} 10, \mathrm{p} 6$.

$94 \mathrm{R} 1, \mathrm{p} 4$; R3, pp 12-13; R6, p 6; R10, p 24; R11, p 4; R12, pp 14-15; R13, p 4; R15, pp 3, 5-6.

95 R1, pp 4, 15; R2, p 4; R4, p 11; R9, pp 7, 17; R11, pp 3, 10; R13, pp 4-5; R15, p 4. 


\section{A. Challenges at the Intersection of Identities}

Four of the fifteen lawyers we interviewed self-identified as racialized. Their personal experiences provide insights into the complex ways in which socially constructed categories of identity interact with each other. Their stories may be viewed as examples of the way in which belonging to more than one stigmatized social category results in more pronounced feelings of 'otherness' in the workplace, especially in big law firms, where success often depends on one's ability to fit into a dominant culture.

Nader, who worked as an associate in a big firm, recalls that it was one person at the firm who created a hostile work environment that drove both racialized and LGBTQ lawyers away from the firm. It seems that the will to control such behaviour by a powerful figure at the firm was limited:

People would not necessarily stand up to him and there was a lot of turning a blind eye to what was being said. A lot of these comments that I mentioned to you were being said to me in front of other partners; including in elevators with other people and everyone else in the elevator just aghast as to what they were hearing. ${ }^{96}$

The comments Nader was referring to were not homophobic; they were directed at his ethnic heritage, but he also had knowledge of anti-gay sentiments expressed by the same person on other occasions. He was therefore apprehensive about coming out at the firm, worrying that he would be under attack for yet another reason ("If people were to find out at my former firm, I'd be mortified."). In other words, quite far from being a 'non-issue,' Nader's gay identity has defined his experience as a young lawyer, and he views it as inseparable from the other components of his identity:

I can't even tell you all the things I've been through personally in my own experience; whether it be a member of the South Asian community, whether it be a member of the LGBT community, whether it being a Muslim. We've been pushed down and pushed down that we do need some assistance to get into the higher ranks. ${ }^{97}$

Nader is now a partner at a different firm, where he feels the culture is very different. A second illustration of the singular impact a handful of senior people at the firm could have on the experience of junior lawyers was provided by Aaron, who worked at a big firm and described the head of his practice group as one of the 'dinosaurs' at the firm:

I heard overtly racist comments from white partners at that firm and there's a huge gulf between the appearance they want to put out and the reality. These dinosaurs...there is nothing you can do about them when you're in a large firm. These men-and I'm using this word consciously, these men who are major rainmakers at firms; there are no rules that apply to them. You can have the most beautifully drafted sexual harassment and diversity policies but these men who are really important rainmakers at these firms... are so important - the money they bring in is so important, no rules apply to them. ${ }^{98}$

Aaron left this firm for several reasons, one of which was the untenable relationship with the 'dinosaur' he worked for at the firm. In reflecting on his experience, he remembers the hostile behaviour as being a

\footnotetext{
96 R12, p 4.

$97 \mathrm{R} 12, \mathrm{p} 11$.

$98 \quad \mathrm{R} 5, \mathrm{pp}$ 2-3.
} 
'substantial' factor in his decision to leave, whereas the 'primary' reason was the realization that the long work hours and the lifestyle dictated by this area of practice were not suitable to him. Interestingly, however, his next move was to another large firm, in the same area of practice (and comparable workload). ${ }^{99}$ At the new firm, he worked closely with a "queer-positive, straight man" and a few years after joining as an associate he made the partnership rank.

The compounding effect of race and sexual orientation was also evident in the case of Sam, who believes he was not able to secure an articling position in several firms where he was interviewed as a student because he did not fit the mold:

I was put in front of men much like that, who were white, able-bodied, heterosexual males who wanted to shoot the shit with me because these were not structured interview processes and there was no way for me to connect with them in any meaningful way based on their particular interest and I think that played a role. ${ }^{100}$

After eventually joining a big firm in Toronto, Sam spent several years there before leaving. He was passed over for promotion to partner despite being one of the top performing associates at the firm. He describes exclusionary practices which impacted his ability to socialize with colleagues at the firm and resulted in biased work allocation and denial of mentorship opportunities:

[T] he boys' club happened outside of the firm because they became friends through this. There were now poker nights, there were now trips to Buffalo for football games and there were all sorts of social opportunities that were denied. That's not a LGBT thing; that's a broader minority and marginalized group thing. I don't think that my experiences are necessarily specific to me as a gay man. I think they are more specific to people who don't fit the mold. ${ }^{101}$

Sam's reflection on the reasons he left that firm, similar to Aaron's, explicitly acknowledges his efforts, at the time, to rationalize his departure (to himself and to others) as a 'lifestyle choice,' given the challenging work realities of a junior associate:

The reality with a lot of Bay Street law firms is that we are all service lawyers except for a few rainmakers. So, you work incredibly long hours to create something that isn't your own. That was becoming increasingly challenging for me and that was what I presented. The reality was that I felt, in a lot of ways, that I have fallen through the cracks. I didn't have an advocate at the firm and as a result, my career was going to suffer. That was indirectly related to my sexual orientation. ${ }^{102}$

After leaving the firm, Sam became a partner in a smaller firm. While he recognizes that unlike 15 years ago, when his career started, firms today make conscious efforts to welcome diverse cohorts of articling students and associates, in his view the challenges remain with retention and promotion because of the

99 The hindsight rationalization may be influenced by his choice to leave private practice altogether, which came several years later.

100 R2, p 4.

101 R2, p 9.

102 R2, p 2. 
persisting social hierarchies within the firms. Nader, Aaron and Sam started their legal careers between 10 and 15 years ago. Robert, another gay lawyer who identifies as racialized, has a more recent experience. He began working as a summer student about 7 years ago, in a firm he describes as 'old school.' The conservative work environment, although not overtly unfriendly or hostile to employees from diverse backgrounds, made him uncomfortable ("you couldn't bring your entire self to work, I guess... I never really knew where I stood in terms of what I could say about my personal life."). ${ }^{103}$ For this reason, he decided not to pursue a position with this firm after graduating. Robert is now a senior associate at another large firm. To him, the barriers to advancement in the legal profession are more about race than sexuality:

I personally find it much harder to advance as a person of colour than I do as a gay man on Bay Street. Based on what I've seen, I think white, gay, men do quite well; people of colour, of any sexual orientation, or gender identity... I find people of colour face greater barriers. So, as a gay man of colour, I find it sometimes a bit rich, when white gay men complain about advancing. ${ }^{104}$

In his conversations with friends who are gay white lawyers, Robert says, he hears that they do not see any reason why they could not succeed in their firms, sometimes at the cost of some degree of selfcensorship (namely, passing as 'straight'). For him, however, the visibility makes his 'otherness' experience unavoidable:

[O]n my side, I can talk about my dating life - my boyfriend - quite openly. It's more the other things that I find make me the 'other' - like, being Chinese and I grew up in a working-class household. Those are the barriers, I feel, that make me different from the [average] partner; it's not me being gay. ${ }^{105}$

Later in the conversation Robert explained that the statement "it's not me being gay" is not meant to imply that his sexual identity is not a potential barrier. But while racial identity cannot be concealed, 'gayness' may be regulated:

[Y]ou can calibrate your degree of 'gayness' based on whom you're with, right? I actually do this. When I'm with whom I know to be a really kind of 'bro's bro' partner - and I do this and there's quite a few of them, I do calibrate my gayness. I become more 'bro'. ${ }^{106}$

Robert is on a partnership track at the firm and he is hopeful about his prospects of making partner, although he is also acutely aware that out of the dozens of partners at the office, only a few are of Asian heritage. A white associate (straight or gay), he believes, has better opportunities for advancement in this firm because he could better connect with a senior partner, who comes from a similar background. He sees around him (white) colleagues, who are able to forge meaningful relationships with influential partners. These mentoring relationships result in opportunities to work on significant files, frequent introduction to important clients, and they consequently better position the associate when he is up for partnership.

\footnotetext{
103 R8, p 4.

104 R8, p 2.

$105 \mathrm{R} 8, \mathrm{p} 3$.

$106 \mathrm{R} 8, \mathrm{p} 31$.
} 
While our sample of lawyers in this study is quite small, the fact that four out of the five negative experiences shared with us were by gay men who are also racialized may not be coincidental. It confirms the research on the effects of intersectionality in the workplace and it suggests, in our context, that the combined impact of race and sexual orientation could be doubly damaging in a predominantly white, heteronormative environment such as a big law firm. We would expect gender and sexuality to have a similar compounding effect, but given the low number of female participants in our study we were unable to draw similar conclusions. ${ }^{107}$

\section{B. Navigating through a Heteronormative Workplace}

David worked in a large Toronto firm for a decade, advancing from the associate level to a non-equity partnership. Reaching the next level (of equity partner) required the kind of relationship building with senior colleagues that was made difficult by the culture of the firm. David was out at work to close colleagues but had to use caution when interacting with others. He first described his experience in the firm as an outsider, mostly because the lifestyle did not suit him:

[N]ot everyone wants to work in a law firm. You have to have certain personality to work in a law firm for a long period of time. I came to the realization that fundamentally - it's not because I was LGBT or not - it was because it wasn't what I wanted to do. ${ }^{108}$

Five years ago, David left the firm to work as in house counsel in a Fortune 500 company, where he finds the organizational culture much more inclusive. Upon further reflection on how different the work environment in the law firm was, he observed:

The fact that you're different and that you feel different and also probably you don't share as much as someone who would have a family and a wife who just had kids and all that. You tend to filter things so you're not as free with details about your own person life, and you're always a bit guarded so it affects your behaviour. I've never really been a guy's guy; I don't like going to hockey games, sports, and all that...it's just who I am. But that's not a LGBT thing, it's just who I am. ${ }^{109}$

While repeatedly separating the outsider experience from his sexuality, the exclusionary practices David experienced created a culture he believes was not friendly to all women and to men who are not 'guy's guys'. He described a lounge in the firm, where partners would socialize and engage in 'boy chat':

Women would come in and never felt really comfortable and LGBT as well. It was the weirdest thing. I've never seen that even in high school... I would go there because I had to but it was like taking bad medicine. ${ }^{110}$

107 For a review of intersectionality research in organizations see Jenny K Rodriguez et al, "The Theory and Praxis of Intersectionality in Work and Organization: Where Do We Go from Here?" (2016) 23:3 Gender, Work \& Organization 202.

$108 \mathrm{R} 14, \mathrm{p} 14$.

109 R14, p 7.

110 R14, p 15. Comments, such as law firms are still often run like boys' club, were also made by R2, pp 2-3, 9; R4, p 16; R7, p 9; R10, p 19; and R11, p 9. 
David, like other lawyers we spoke with, describes an organizational culture that is not characterized by overt discrimination against women or explicit homophobic actions. Rather, they describe a culture that maintains a heteronormative order, where gender roles and sexuality are defined in complex ways. ${ }^{111}$ The concept of heteronormativity is useful in understanding the institutional and rhetorical effects of practices such as the 'lounge' described by David. Whereas homophobia manifests itself through direct discrimination (and can thus be outlawed), heteronormativity operates in more subtle ways and it is therefore much more challenging to address:

The concept of heteronormativity reveals institutional, cultural and legal norms that reify and entrench the normativity of heterosexuality. In other words, 'heteronormativity' tells us that heterosexual desire and identity are not merely assumed, they are expected. They are demanded. And they are rewarded and privileged. ${ }^{12}$

'Heteronormativity' captures two related but distinct aspects of a heteronormative workplace: It is both patriarchal (namely, male-dominated) and it renders other sexualities marginal. The impact it has on the experience of both women and sexual minorities is particularly pronounced in law firms, where relationship building is so critical for success, and therefore socializing practices with colleagues and clients can make a real difference to lawyers, who try to work their way to the upper ranks.

A heteronormative workplace is where heterosexuality is presumed, and where everyone, straight or gay, is judged against the 'normality' that gender and sexual norms dictate. ${ }^{113}$ The need to constantly perform the act of coming out to colleagues and clients (because of the presumption of heterosexuality) was a common experience of the gay and lesbian lawyers we spoke with. Several of them contrasted the 'straight' way in which they had to carry themselves at work and a flamboyant behaviour (described as 'flaming' or 'out there') they would avoid because they thought it would not be acceptable on Bay Street. Recall Robert's comments about how he 'calibrates gayness' and matches it to his audience. His concern was that performing his sexual identity could make it as visible as his ethnicity, and would therefore come at a cost. Such passing into 'normality' was a common theme in the comments we heard. ${ }^{114}$

The heteronormative workplace is also where (heterosexual) men assume the role of breadwinner in their household and are typically not involved in child rearing. This allows them to spend long hours at the office and ambitiously work their way up to leadership positions. Sam, who we met earlier, believes that in this context, gay men could have an advantage in a work environment that rewards complete devotion to the firm:

The reality is, we are still unlikely to have children. A lot of us have a chip on our shoulder and have something to prove. We are the new white, able-bodied heterosexual male. We are prepared to give up everything for our careers because we want to prove something to the world, and so we tend to be very high performing. ${ }^{115}$

111 Where friendships are formed over a glass of beer, in a sports bar or at a golf retreat (R6, p 10; R8, p 22) and where conservative clients or the traditional corporate culture of law firms impacts one's ability to form relationships and get work assigned (R1, pp 5-6; R2, pp 3-4; R4, p 16; R6, p 10; R10, p 14; R15, p 9).

112 Samuel A Chambers, ““An Incalculable Effect': Subversions of Heteronormativity” (2007) 55 Political Studies 656 at 665.

113 Elaine Swan, "A Testing Time, Full of Potential? Gender in Management, Histories and Futures" (2010) 25:8 Gender in Management: An International Journal 661 at 668-69.

114 As David noted: “You don't want to rock the boat and you don't want to draw attention to yourself" (R14, p 6).

115 R2, p 4. 
But an increasing number of gays and lesbians are now partnered and have children. In fact, part of the normalizing process of lesbian and gay individuals and their induction into the heteronormative culture began with the decoupling of homosexuality from sex, and in their inclusion in heterosexual social institutions such as the family. ${ }^{116}$ Some of our participants were acutely aware of this normalizing process:

[B]ack in the 70s, when people thought of gay men, they thought gay sex... but now it's much more: you're gay because you have a gay boyfriend at home... I think it helped advance [gay men]. That's why I feel on Bay Street, white gay men can advance because it's no longer about them being 'perverts'. It's about 'They're just like me!'117

The political project of the LGBTQ movement is often criticized because its rights-based fight for equality is centered on a 'sameness' argument, which has the potential to negate difference rather than accept it. This movement advances the argument that LGBTQ individuals should have the same access to core institutions in society as heterosexuals, because they seek the same ideals of family and intimate life. The package of rights and responsibilities may include pension benefits, parental rights, inheritance recognition, joint income benefits, and the most recent achievement of the movement is the growing recognition of the right to marriage. In different ways, these efforts to integrate gays and lesbians into society arguably reinforce existing gender and sexual values as the preferred way of life. ${ }^{118}$

Emma, a lesbian woman, who is a partner in a large firm, found a way to both come out and bond with male colleagues and clients who, like her, have a wife at home:

We will be in a meeting and say, 'I got to get home or else my wife's going to kill me.' And I'll say, 'Oh, me too.' And suddenly we have this really weird kind of connection where you're telling wife stories and they really get it, and they suddenly really get you. ${ }^{119}$

Since her spouse is the one who carried their children and was the primary caregiver, Emma was able to assume the role expected of a successful lawyer in the firm - that of the heterosexual male, who is relatively unburdened with familial obligations. In one situation, Emma recalled, a client was 'greatly relieved' to learn that while she is expecting a child, she is not the one carrying the baby and through this, he understood that there will be no 'interruption' in the work on his file. ${ }^{120}$ In these ways, Emma feels she has an advantage over women who find it more challenging to 'connect' with male colleagues. If she were straight, her male colleagues and clients would have assumed that her family obligations come first ("Oh no, I shouldn't keep you at this meeting because your husband's going to be angry!'”). ${ }^{121}$ These oppressive gender expectations, in turn, could have real consequences for women in terms of work allocations and ultimately, advancement in the firm.

Emma's story may be viewed as an example for the ways in which the presumption of heterosexuality in law firms is being successfully challenged and undermined by lesbian and gay lawyers. These acts of

\footnotetext{
116 See generally Michael Warner, The Trouble with Normal: Sexual Politics and the Ethics of Queer Life (Cambridge, MA: Harvard University Press, 1999).

117 R8, p 31.

118 For a review of critiques see Diane Richardson, “Locating Sexualities: From Here to Normality” (2004) 7:4 Sexualities 391.

119 R9, p 14.

$120 \quad$ R9, p 14.

$121 \quad$ R9, pp 14-15.
} 
coming out and 'connecting' with straight men on the basis of familial expectations seem to subvert gender roles while working within the terms of heteronormativity: Every time Emma comes out to colleagues or clients, she challenges their assumption that she is a straight woman, as well as the assumption that as a woman, her commitment to the firm has real limitations because of family obligations (childbearing, child rearing) which render her less 'valuable' to the firm and to its clients. As others have noted, however, such acts of subversion may shore up heteronormativity as much as they are likely to challenge it. ${ }^{122}$ And in our example, while Emma and many other LGBTQ lawyers who formed families may question heterosexual assumptions about gender roles, the underlying norms continue to prevail, resulting in little progress.

The stories of gay lawyers we encountered earlier demonstrated the challenges of sexual minorities in a hyper-masculine work environment: their experience has taught them that you are more likely to succeed in the firm if you act as a 'guys' guy' or a 'bro.' Their comments reflected concerns about the mismatch between the characteristics associated with 'flaming' gay men and the heterosexual masculinity associated with professional success. Calibrating 'gayness' was seen as crucial, even in seemingly gay-friendly firms, in order to survive and thrive. Emma's story suggests that in a similar fashion, lesbian lawyers navigate through the heteronormative workplace by performing their identity in a manner that distances them from stereotypes associated with women. ${ }^{123}$ One such stereotype is the belief that women are not sufficiently committed to the firm, because they are likely to work fewer hours, and could not bill the same number of hours as their male counterparts. This stereotype has real consequences for advancement prospects. It may lead rational decision makers within the firm to systematically prefer male associates to female lawyers. And the stereotypes tend to be a self-fulfilling prophecy. Because of the stereotype, male associates will likely receive better assignments, superior mentorship, and advanced training. Over time, male associates will have more and superior opportunities to become better lawyers, rationalizing the biased decisions against women attorneys. ${ }^{124}$

The impact of such gender stereotypes is particularly pronounced given the prevailing professional ideology in large law firms. The growing commercialization of legal services and the fierce competition between firms, in combination with the economic downturn of the late 2000 s, has led firms to adopt an 'around-the-clock' service mentality to clients and this resulted in an expectation from both partners and associates to demonstrate complete loyalty and devotion to the firm. ${ }^{125}$ This mentality, Eli Wald argues, became part of the definition of excellence in hiring and promotion practices, and it now forms a part of what is a 'hypercompetitive meritocracy' governing large law firms. ${ }^{126}$

\section{The Limits of Diversity Programs: Hiring Practices, Committees, and Affinity Groups}

Large firms responded to the challenges facing equity-seeking groups in at least three important ways. First, by taking measures to ensure that the summer/articling classes become increasingly diverse. Second, they have set up diversity committees and affinity groups that aim to foster an inclusive work environment. And third, they established formal mentorship programs for junior lawyers. As our conversations with the

122 See Chambers' discussion of Judith Butler's example of drag performances as subversive acts. Supra note 112 at 671-76.

123 See Deborah Rhode, The Unfinished Agenda: Women and the Legal Profession (American Bar Association Commission on Women in the Profession, 2001).

124 Eli Wald, "Glass Ceilings and Dead Ends: Professional Ideologies, Gender Stereotypes, and the Future of Women Lawyers at Large Law Firms" (2010) 78 Fordham L. Rev 101 at 131 [Wald, "Glass Ceilings"].

$125 \mathrm{Ibid}$ at 114-29. See more generally, on the ways in which institutional and ideological structures compromise the profession's ethical commitments, Deborah L. Rhode, "Ethics in Practice", in Deborah L. Rhode, ed., Ethics in Practice: Lawyers' Roles, Responsibilities and Regulation (New York: Oxford University Press, 2000) 3.

126 Wald, "Glass Ceilings", supra note 124 at 128-29. 
participants revealed, while these efforts have had some clear achievements, their impact has been limited to the lower ranks of firms.

The majority of participants (ten of the fifteen) described their personal experience at the firm as positive. There was also a general acknowledgement, however, of the role unconscious bias may play in hiring and promotion practices. ${ }^{127}$ Participants who have done well for themselves attributed their success to luck or good fortune in overcoming these potential obstacles. While some cited a 'pipeline problem' (i.e. not enough LGBTQ lawyers apply to big firms, perhaps given their natural gravitation toward more creative career paths), ${ }_{128}$ or a growing interest in a better work-life balance that millennials expect and that law firms are unable to provide, ${ }^{129}$ the majority described the hiring process of law students as fairly subjective and therefore more likely to reproduce homogeneity. Surprisingly, our participants often defended prevailing practices around the hiring process. ${ }^{130}$ While appreciating the risks in a subjective assessment of candidates, they explained that due to the nature of the legal practice, which requires a strong personality or 'people skills', there is no way to find a 'good fit' other than through conversational interviews with candidates. ${ }^{131}$ They did not seem to know what hiring practices could achieve this purpose while avoiding the collateral damage of implicit bias other than diversity and unconscious bias training.

The initial screening of student applications to law firms is based on academic achievements, and only the top performing students are interviewed. The On-Campus Interview $[\mathrm{OCI}]$ process and the in-firm interviews are based on casual conversations, where recruiters are mostly looking for the best 'fit':

...[P] eople want to work with like individuals. You spend so much time in a law firm it becomes a bit of a second family. I think that becomes a bit of the obstacle in that you're always promoting the same people, the same fit, a certain profile, a certain mold. ${ }^{132}$

Sam, who we met earlier, interviewed with over a dozen law firms in the city and was not able to secure an articling position in any of them. The firm where he got hired (in a different city) was the only one that used a panel interview format for hiring students, with a set of pre-determined questions that each candidate was asked. The student intake at that firm, he recalls, was particularly diverse as a result. Only when asked directly, a few participants agreed that a more standardized hiring process, perhaps with a scripted questionnaire and set metrics, could address the potential bias in selecting the best candidates. ${ }^{133}$ One participant noted that his firm's leadership team put in place more 'objective' measures, by including checklists that recruiters must fill out, asking them to assess the skills and aptitudes required. While this is a move in the right direction, he maintained, the decisions continue to be largely subjective. ${ }^{134}$

Sam's experience (who started his career over 15 years ago) may not be representative of the impact of the OCI hiring process on law firm diversity today. Over the past few years, large Canadian law firms have consciously diversified the student intake and the incoming cohorts are much more representative of graduating law school classes than before. This is done partly through ensuring, for example, that the lawyers assigned to interview the candidates come from diverse backgrounds, which arguably makes these

127 R2, p 19; R4, p 10; R5, p 10; R6, pp 6-7; R7, pp 11-12; R8, pp 15-16; R10, p 18; R11, p 6; R12, pp 5, 12.

128 R11, p 10-11; R13, p 22.

129 R1, pp 11, 14; R3, p 10; R5, pp 5, 7; R6, p 7; R10, p 23; R11, pp 9, 11; R13, p 9; R15, pp 14-15.

130 R3, p 16; R4, p 10; R5, pp 9-10; R10, pp 16-18; R13, pp 6-7.

131 R5, pp 9-10; R7, pp 11-12; R8, p 14; R9, pp 6-7; R10, pp 16-17; R12, p 12; R13, p 7; R14, p 12.

132 R14, p 17, and similarly stated in R2, pp 3-4; R3, p 16; R4, pp 8, 10; R5, pp 9-10; R8, pp 14-15; R9, pp 6-7; R10, p 18; R11, p 6; R12, p 12; R13, p 7; R15, p 10.

133 R2, p 18; R7, pp 11-12; R9, p 21; R11, p 6; R12, p 13, R13, p 8.

134 R11, at $\mathrm{p}$ 6-7. 
casual interviews less awkward than they otherwise would be. ${ }^{135}$ The hire-back ratios, in turn, are fairly high and as a result, the associate rank in many of the firms is not as homogeneous as it used to be. The challenge with respect to all minority categories remains in retention and promotion. ${ }^{136}$

Michael is the most junior lawyer we spoke with. He is in his first year as an associate at a large Toronto law firm. His path may be representative of the current openness and acceptance experienced by gay and lesbian lawyers entering the profession. Michael attended an LGBTQ professional networking conference in his first year of law school, and made connections that he later leveraged when applying for summer and articling positions at various firms. Soon after joining the firm he started an LGBTQ affinity group with the firm's blessing and support. He thought it was a great opportunity to promote an inclusive work environment and that strategically, it could benefit him personally ("it would be foolhardy of them to make someone the lead of... Pride Network and not hire them back!"). ${ }^{137}$

As the affinity group lead, Michael makes efforts to bring together LGBTQ lawyers from across the firm, who participate in socializing events, Pride Week celebrations and professional development activities targeting LGBTQ lawyers and allies. He is often called upon to meet prospective summer/articling students who make their sexual orientation evident when applying to work at the firm. His message to candidates is that the firm is very LGBTQ-friendly and that as a gay lawyer, he is very comfortable being out in the firm. He is therefore an active contributor to the firm's efforts to appeal to diverse talent and to signal to prospective employees that being openly gay at the firm is not just tolerated; it is supported and celebrated.

Michael's story so far illustrates what Eli Wald has termed "implicit capital exchange" in law firms. ${ }^{138}$ Wald suggests that diversity in firms can only be enhanced through an understanding of the role capital plays in the hiring and promotion of lawyers within firms. He argues that firms and lawyers constantly engage in complex transactions where they exchange economic, social, cultural and identity capital. ${ }^{139}$ The firm typically provides incoming associates with short-term economic capital (in the form of lucrative pay) as well as opportunities to enhance their social and cultural capital (through training, mentoring, and access to valuable relationships that may help them develop their own book of business). Ultimately, the firm also offers them a shot at long-term economic capital in the form of partnership rank. ${ }^{140}$

The lack of transparency around the nature of this labour-capital exchange, Wald argues, results in the underrepresentation of women and racialized lawyers in big law firms. The focus on equal treatment of all through an objective assessment of junior lawyers confuses merit with capital. Associates who come into the firm endowed with substantial social, cultural and identity capital (typically white males) have

R3, p 16; R4, pp 9-10; R8, pp 15-16; R9, pp 5-6, 23; R10, pp 8, 16; R11, pp 6-7.

R2, p 16; R5, p 9; R12, pp 11-12; R13, pp 4, 7; R14, p 2.

R3, p 4.

138 Eli Wald, "BigLaw Identity Capital: Pink and Blue, Black and White" (2015) 83 Fordham L Rev 2509 [Wald, "BigLaw"]. Michael seems to be relatively mindful of the exchange (describing the valuable work he did for the firm and his expectation that it would be rewarded). Others realized they are the diversity 'poster-child' for the firm (as R4 defined himself, p 21), but did not express a similar perspective on reciprocity. Another participant told us he was always sent to meet gay and lesbian candidates at the interview stage, even though there was never a conversation with him about this practice and its purpose (R10, p 4), which again speaks to the implicit ways firms extract lawyers' identity capital.

139 Social capital is defined as an individual's membership in networks that extend to its members benefits by virtue of membership. Cultural capital includes communication skills, cultural awareness, knowledge of institutions and credentials that provide access to socioeconomic mobility. Identity capital refers to value derived from different facts of one's identity: race, gender, class, or sexual orientation, which triggers positive reactions and perceptions or stereotypes (Wald, "BigLaw", supra note 138 at 2519-29).

140 Ibid at 2529-32. 
greater success at the firm because their capital is often misrecognized as merit. Women and racialized minorities are negatively impacted because they tend to have lower capital endowments (due to prevailing stereotypes), and while firms often attempt to extract identity capital from diverse lawyers (in order to appear more diverse), they fail to properly reciprocate in a way that positions all lawyers on equal footing. ${ }^{141}$

These insights can be applied to the relationship gay and lesbian lawyers may have with large law firms. In fact, Michael's professional journey so far, as an example, reads like a fair (if implicit) exchange with the firm: he was offered an opportunity to develop economic capital, cultivate connections that would improve his social and cultural capital, and he is reciprocating by enhancing the identity capital of the firm (i.e. appearing progressive and diverse). ${ }^{142}$ Interestingly, however, when considering his future in the firm, Michael does not think that his work on LGBTQ initiatives and his contribution to the diverse image of the firm will play a meaningful role in his promotion, other than signal loyalty to the firm. He believes he will be evaluated based on his skills and performance, as reflected in his ability to meet the billable hour targets and capacity for client development. Non-billable contributions to the firm (of all kinds) are an expectation but in his view, they are not 'deal breakers.' ${ }^{143}$ In other words, the implicit capital exchange only goes so far. It may help lawyers who choose to leverage their identity capital in their early tenure in the firm (and the firm benefits from the value that it brings), but it may not be useful beyond the associate rank.

In some ways, the firms' support for the establishment of diversity committees and affinity groups makes a positive contribution to the development of social capital among diverse lawyers. Diversity committees were initially created within firms to address the gender gap, and later broadened their mandate to consider other underrepresented groups. ${ }^{144}$ Most large Canadian firms have such committees, and their mandates are typically stated on their website. Their initiatives may include organizing diversity training for lawyers and recruiters, participation in awareness-raising campaigns, employee engagement surveys, and representing the firm in various inter-firm initiatives such as the LFDIN discussed earlier. Affinity groups tend to be less formal and structured, although some firms have developed policies for setting up such groups. ${ }^{145}$ The LGBTQ affinity groups (often labelled "Pride Network") have only sprung up in firms over the past few years. This loose association of employees at the firm (both lawyers and staff) organize social activities, plan firm Pride parties, support various campaigns such as Pink Shirt Day and National Coming Out Day, hold information sessions and panel discussions on LGBTQ family issues

141 Ibid at 2536-39.

142 As Wald convincingly argues, institutions can possess capital as well. For example, "the rise of large WASP law firms to prominence in the late nineteenth through the mid-twentieth centuries very much depended on their ability to translate their elite ethno-religious and class identity as WASP and white-shoe institutions into elite professional identity" (ibid at 2526-27). Today, diversity is a value that firms increasingly embrace as part of their identity. See David B Wilkins, "From 'Separate is Inherently Unequal' to 'Diversity is Good for Business': The Rise of Market-Based Diversity Arguments and the Fate of the Black Corporate Bar” (2004) 117 Harvard L Rev 1548.

143 R3, pp 9-10.

144 How effective these initiatives are in closing the gender gap is still under debate. It is often argued that while diversity committees assist in initial recruitment, they have very little impact on partnership decisions. See e.g. a recent NAWL study, indicating that despite being hired in nearly equal numbers as men at the associate level, only $19 \%$ of all equity partners in the U.S. are women, reflecting a very small upward change from $16 \%$ in 2007 . National Association of Women Lawyers, Annual Survey Report 2017: The Promotion and Retention of Women in Law Firms (2017), online: $<\mathrm{http}: / /$ www.nawl.org/p/cm/ld/fid=1163>.

145 R4, p 6; R11, p 13. For a typology of such groups see Rod P Githens \& Steven R Aragon, "LGBTQ Employee Groups: Who are They Good for? How are They Organised?” (2007) Adult Education Research Conference Proceedings 2007, online: <http://newprairiepress.org/cgi/viewcontent.cgi? article=2524\&context=aerc $>$. 
(parenting, wills and estates) and in rare cases engage in advocacy by urging the firm to consider revising its benefits policies (e.g. on maternity and paternal leave).

Participants' views on the benefits of affinity groups in helping diverse lawyers advance ranged from celebratory to cynical. Michael, for one, believes that the opportunity to socialize with other LGBTQ lawyers within the firm, who are at different stages in their careers, provides the emotional support that may help overcome low points in the associate's journey to the partnership rank. Concern over the loss of work-life balance is an issue that makes many junior associates second-guess their career paths, and the support network that affinity groups provide may tilt the scale in favour of working through it ("It's more like a family, I don't mind working long hours because the people I work with are like friends"). ${ }^{146}$ In this sense, affinity groups provide a social support network that is not related directly to advancing the cause.

Aaron, on the other hand, describes the recent efforts by firms to create an inclusive workplace as 'pink washing', 'fluff' and 'window dressing.' In his view, beyond being effective marketing tools and fostering a measure of 'feel-good,' these initiatives will not resolve the structural barriers facing equity seeking groups:

\section{The affinity group is all very well and good, but it doesn't address the core issue that your success at a firm depends on having that partner who really likes working with you and having the partner who has the consistent, reliable, dependable source of good, lucrative client work. The affinity group just doesn't help. ${ }^{147}$}

Aaron is alluding to the kind of social capital that may help associates reach the next level - creating meaningful and mutually beneficial relationships with influential partners at the firm. Our participants (whether associates or partners) who are not directly involved in the promotion process in their firms knew very little about what promotion entails. Their view is that the process is not particularly transparent, and they referred to the decision-making process as a 'black box.' 148 But they all believe that their advancement will depend (or depended, in the past) on the support from the head of their practice group, as well as others in the firm (mentors, sponsors and other partners they work for) who would vouch for them when decision time comes.

The support system that allows associates to devise ways to form such relationships varies across firms and it reflects the firm's effort to provide associates with opportunities to cultivate their social and cultural capital. Most participants told us that their firms have a formal mentorship program, but they also knew that participation of partners in this program is non-billable and for this reason, the level of their time commitment varies greatly. The most effective and meaningful connections are often organically formed with partners who can personally relate to the associate and act as their mentor or sponsor. ${ }^{149}$ As we saw above, the lawyers who had the most difficult time receiving support from partners in the firm were both gay and racialized. ${ }^{150}$ Robert, for example, said:

\footnotetext{
146 R3, p 13.

147 R5, p 9; R8, p 13 (“We say we're diverse, we say-we advertise ourselves as a gay-friendly firm, so that's what makes it diverse but that's not actual substantive diversity.")

148 R5, p 6; R8, p 11; R9, pp 11-12; R10, pp 9-11; R13, p 13; R14, p 7; R15, pp 19-20. Quite often, the extent of information shared with associates is that the criteria for partnership is whether the associate is "making a sustainable contribution to the firm" (R11, p 12).

149 R2, p 3; R7, pp 7-8; R8, pp 8-9; R10, pp 11-13; R11, p 9; R12, pp 9-10; R13, pp 9-10; R14, p 7; R15, pp 4-5. Similar to what Pearce et al argue in the U.S. (supra note 62 at 2418-19).

$150 \quad$ R2, pp 13-14; R4, pp 12-13; R8, pp 8-9, 26.
} 
I would want to attach myself to someone who would bring in a lot of work and I can learn a lot from; who would most likely be a white male partner, but I have nothing in common with that white male partner. Even if I wanted to do-have that connection... I have [tried]; but I'm just not their person of choice. ${ }^{151}$

It is often argued that the challenge in making law firm partners devote time to helping diverse lawyers advance is that unlike corporations, partnerships are more difficult to manage because they are more like a collection of sole practitioners than a hierarchical organization. ${ }^{152}$ Yet, several participants disagreed with this view. With the creation of tiered partnership tracks in law firms, power has become more concentrated and decisions regarding criteria for compensation, for example, are being made by a small group of senior partners. ${ }^{153}$ This small group, often in the form of an executive committee, could decide to include diversity considerations in the compensation scheme:

If an executive committee at a law firm said, 'Right now our compensation is based on how much you work in a year, how much work you give to other people,' so how hard are the associates under you working, 'Did you bring in clients?' There's a whole matrix of factors... What if part of it was, 'What did you do to advance [the] diversity of your group? ... Did you mentor somebody? Did you make it a point to give some work?' Think about it, that's the only motivating factor in a law firm - compensation. ${ }^{154}$

One large law firm we heard about from a participant is the outlier: rather than basing its compensation scheme on origination credits (by asking who brought the file/client into the firm), compensation decisions are made on the basis of both billable and non-billable work hours, and these are considered regardless of who brought the file into the firm. This approach, initiated by the founders of the firm, fosters collegiality and most importantly, it allows them to sidestep the often-contentious question "Who originated the file?" and instead considers each partner's actual contribution to the firm, using both billable hours and other factors (i.e. mentoring of junior lawyers). This approach reportedly drives the firm culture and works in favour of both partners and associates who do excellent work but may not have access to the networks that others can leverage to drive business development:

[Y]ou feel like clients are clients of the firm and not your personal clients. Then people don't build fiefdoms; we're very proud to have strong stable corporate clients that we've had for many years and they're not attributable to any particular person. I think it probably was easier for someone like me to succeed in an environment like that. ${ }^{155}$

Structural obstacles, then, have a real impact on the organizational culture of the firm and its ability to address the diversity gap in a meaningful way. The majority of law firms do not recognize non-billable

$151 \mathrm{R} 8, \mathrm{p} 26$.

152 R5, pp 2-4; R6, p 17; R8, p 10; R11, p 15; R13, p 25; R14, pp 8, 12.

153 Indeed, several participants stressed that a meaningful change is possible if only senior management was more interested in and championed diversity (R2, pp 10-12; R10, pp 21-22; R11, p 18; R13, p 15; R14, p 14).

154 R11, p 15. Also: R4, p 19; R7, p 13-14; R13, pp 23-24; R14, p 14; R15, pp 16-17.

$155 \mathrm{R} 15, \mathrm{p} 17$. Whether this compensation structure resulted in a more diverse leadership in this firm remains unclear, given that the demographic information is not publically available. It also cannot be confirmed whether other firms followed suit given that compensation and promotion schemes are not made public either. 
contributions to the firm in the same way that they reward billable hours and as a result, senior partners often lack the incentive to dedicate time and effort to helping associates with limited social and cultural capital to develop to their full potential.

\section{CLOSING THE DIVERSITY GAP: WHAT WORKS AND WHAT DOES NOT}

Kalev et al conducted a study of hundreds of U.S. mid-sized companies comparing the effectiveness of three different approaches to the advancement of diversity. First is the organizational approach, where companies use various forms of affirmative action, oversight and advocacy through diversity committees and staff appointments to monitor diversity. The second approach focuses on reducing social insulation by establishing mentoring and network programs to change employee relationships. Finally, a behavioural approach uses diversity training and performance feedback in efforts to reduce managerial bias. The authors found that companies that advanced an organizational approach were able to increase diversity in the most significant way. ${ }^{156}$

In Section IV, we reviewed the initiatives implemented by big law firms in response to the mounting pressure to diversify their ranks. These efforts can be placed across all categories in the typology Kalev and her colleagues propose: prompting behavioural change by mandating diversity training, reducing social insulation through mentorship programs for junior lawyers and support for affinity groups, but also intentional recruitment efforts of diverse talent and the establishment of diversity committees. Some firms have also implemented employee surveys that provide them with quantitative and qualitative data on the demographic composition of the workforce and the level of inclusiveness of the firm. In this Section, we consider the effectiveness of these diversity programs in light of the interview findings as well as the available research on workplace diversity.

\section{A. Measurement and Transparency}

Within firms, there is broad agreement that data collection and tracking are crucial for the development of efforts to address the diversity gap. ${ }^{157}$ In fact, some Canadian firms are already collecting information on their demographic composition, but they do not make it public and the measures they use may not be consistent. As a result, the only information available is provided by the LSUC in aggregate form. This is about to change in Ontario, where the LSUC will start reporting information it collects by legal workplaces with 25 licensees or more. The intention is to publish an inclusion index by firm, which includes a breakdown to associate and partnership levels, starting in 2019 and update the index every four years. ${ }^{158}$

Similar voluntary efforts south of the border to publish demographic information on the composition of firms have had limited success in increasing the representation of equity-seeking groups in leadership positions. But this use of data as a 'shaming' tool may work more effectively in the Canadian context, where a relatively small number of big firms dominate the legal services market. ${ }^{159}$ The diversity index

156 Alexandra Kalev, Frank Dobbin \& Erin Kelly, "Best Practices or Best Guesses? Assessing the Efficacy of Corporate Affirmative Action and Diversity Policies” (2006) 71 American Sociological Rev 589. See also Frank Dobbin \& Alexandra Kalev, "Origins and Effects of Corporate Diversity Programs" in Quinetta Roberson, ed., Oxford Handbook of Diversity and Work (New York: Oxford University Press, 2013) 253 (diversity initiatives, which focus on eliminating managerial biases through e.g. training, have been much less effective than initiatives, which focus on workforce integration, through mentoring programs, and diversity task forces).

157 For a discussion see Lyon \& Sossin, supra note 45.

158 See LSUC Committee, Report 2016, supra note 11 at 91.

159 See Canada's large firms in Lexpert Directory, supra note 57. The size and number of large firms in the U.S. is substantially different. 
could operate as a mechanism for social accountability, and provide useful information for prospective employees as well as clients, who may choose to take their business to firms that stand out as diverse and inclusive. The in-house counsel initiatives we discussed earlier indicate that some of the big firm's largest clients have an interest in advancing this cause and may indeed use this information when seeking legal services.

A consistent and reliable measurement across all firms could reveal which of the big firms deliver on their commitment to diversity and inclusion by showing the representation of equity-seeking groups at all levels in the firm. It could highlight the challenges that these firms may have in retaining diverse talent. For example, even when significant progress is shown in the number of gay and lesbian lawyers entering the firm over the years, it would be important to track their representation in the leadership ranks. As we noted in Section V, the general sense expressed by interview participants was that law firms have been making notable efforts to attract diverse talent but often fail to support them along the track toward partnership. A diversity index could substantiate this claim and pressure firms into finding ways to address the gap.

\section{B. Diversity Training}

Diversity training programs have become an essential part of the inclusive workplace toolkit. They are used widely in an attempt to remove bias in hiring and promotion decisions in the corporate sector, and almost all of the participants we spoke with noted that unconscious bias training was made mandatory for all employees at their firm or at least for those on hiring committees. ${ }^{160}$ This conventional wisdom - that training helps people (managers in particular) shed their biases is rarely based on empirical evidence. Pride at Work's guide for best practices, for example, includes a recommendation for organization-wide training which covers a review of discrimination and harassment policies, education on respectful communication, and the organization's policies that support victims of discrimination and harassment. Additionally, when discussing unconscious bias and hiring practices, the guide states: "Recruiters and hiring managers should be trained on the many forms of unconscious bias that play out in the hiring process to ensure they are selecting the best person for the job, regardless of differences." 161

Research suggests, however, that heavy reliance on training programs to overcome bias in management may be ill-advised. In the U.S., nearly all Fortune 500 companies as well as nearly half of midsize companies use training programs, but their effectiveness is being increasingly questioned. In fact, in a study of more than 800 companies, it was found that mandatory training has a surprisingly negative effect. ${ }^{162}$ In companies that mandated training, there was no improvement in the proportion of white women, black men, and Hispanics in management five years into the implementation of the programs. The share of black women and Asian-American men and women actually decreased. One explanation offered by the authors is that compulsory training evokes anger and resistance. The resentment may be derived from the perception that managers are being singled out because they require these remedial measures. On the other hand, when managers feel that the choice to attend training is theirs, they tend to be more receptive to change their practices. More crucially, however, reliance on training is problematic

160 Most participants found training helpful but not enough as they felt unconscious bias was not an easy issue to tackle (R4, p 10; R7, pp 14-16; R8, pp 14-15; R9, pp 20-21; R11, p 6; R12, p 15; R13, p 13). A few questioned its effectiveness or usefulness (R2, p 14; R6, pp 8-9, 11; R10, p 20).

161 Alison Grenier \& Jacq Hixton-Vulpe, Beyond Diversity: An LGBT Best Practice Guide for Employers (Pride at Work Canada, 2017) at 11-13, 25, online: $<$ https://www.greatplacetowork.ca/en/reports/254-beyond-diversity-an-lgbt-bestpractice-guide-for-employers>.

162 Frank Dobbin \& Alexandra Kalev, "Why Diversity Programs Fail” (July-August 2016) Harvard Business Rev 52. 
because "[i]t turns out that while people are easily taught to respond correctly to a questionnaire about bias, they soon forget the right answers. The positive effects of diversity training rarely last beyond a day or two." 163

Another study, which reviewed the literature on diversity training programs on campuses and in the workplace, critically examined the short and long term outcomes of diversity training. ${ }^{164}$ It found that that an integrated approach to diversity training (where "training is conducted as part of a systematic and planned organizational development effort") is more effective but less popular than a stand-alone approach and other diversity programs, which focus on specific groups or on one method of instruction. ${ }^{165}$ It also concluded that the integrated training approach requires "increased commitment of top management."166

Meaningful engagement of managers in diversity programs, Dobbin \& Kalev suggest, is a more effective strategy and it has proven successful in companies that rather than focusing on control, try to include managers in attempts to address the diversity gap (e.g. in targeted recruitments and mentoring programs), expose them to people from different identity groups, and encourage social accountability for change (e.g. through diversity task forces). Some of the tactics they recommend are relevant to the law firm context and we will address them here in turn: management practices focusing on targeted recruitment and mentoring programs, and the establishment of diversity task forces.

\section{Management Practices: Targeted Recruitment and Mentoring Programs}

Law firms recruit prospective employees as early as second year of law school, as we saw above. While the initial screening is based on a seemingly objective measure (top grades), the following stages of the recruitment cycle are inherently subjective. In the search for the best 'fit,' recruiters inevitably reproduce homogeneity when selecting candidates. The hiring practices in big firms have not changed over the years, and they continue to be based on assessments that may exclude members of different identity groups. We heard of two exceptions to this general practice. One was of a midsize firm that introduced standardized interview questions for all candidates (which reportedly resulted in very diverse cohorts entering the firm). Another was an attempt to provide guidance to recruiters by giving them forms to fill out, where the desired aptitudes and skills are identified and measured.

While the hiring process remains largely subjective, we also heard from participants that some law firms are making efforts to attract gay and lesbian talent by engaging gay and lesbian associates and partners in the recruitment efforts of students. Associates involved in the hiring process, we argued above, appear to be trading their identity capital by taking part in the firm's effort to project an inclusive and diverse image. The lack of transparency of this exchange, however, suggests that the rewards for gay and lesbian lawyers may not necessarily help them advance very far in the firm.

Dobbin \& Kalev, in their large-scale study, considered the success of college recruitment programs that target underrepresented groups. Studies suggest that engaging managers in these efforts converts the 'wishy-washy' managers and brings them to think of themselves as diversity champions. Once they get involved in the recruitment of employees from underrepresented groups, they also become convinced that their protégés merit advancement opportunities and as a result, the representation of equity-seeking groups in management positions improves dramatically. In our context, however, this practice can only go so far given that the gay and lesbian lawyers sent to recruit diverse talent are the hiring managers for the purpose

163 Ibid. See also Peter Bergman, "Diversity Training Doesn't Work” (March 2012) Harvard Business Rev.

164 Katerina Bezrukova, Karen A Jehn \& Chester S Spell, "Reviewing Diversity Training: Where we have been and where we should go" (2012) 11:2 Academy of Management Learning \& Education 207 at 220-21.

165 Ibid at 221-222.

166 Ibid at 222. See also the studies referenced in supra note 80. 
of recruiting students, but they are typically not the ones involved in promotion decisions down the road. As a result, the changes we see in big firms in addressing the diversity gap do not extend to their upper echelons.

Mentoring programs are another demonstrated way to diversify the workplace as they help engage managers and "chip away at their biases." 167 It gives these senior members of the organization a stake in the cause and they become champions for their protégés. Formal mentoring programs tend to benefit junior employees from underrepresented groups, who are less likely to develop such relationships on their own. In the 829 midsize and large companies studied by the authors, mentoring programs improved the representation of racialized employees in management by $9 \%$ to $24 \%$ within five years. ${ }^{168}$

Most big law firms in Canada have established mentoring programs and the lawyers we spoke with confirmed that such formal relationships exist. Just like racialized lawyers reported in the LSUC study, however, our participants made an important distinction between mentorship and sponsorship. In most cases, mentoring is not a billable contribution to the firm and for this reason, the level of time commitment and energy invested by mentors varies. Meaningful relationships tend to develop informally, typically within the same area of practice (and therefore involve assignment of work on important files). As observed by our participants, such helpful sponsorships are more likely to occur within the same identity groups.

\section{The Establishment of Diversity Task Forces}

Diversity task forces, Dobbin \& Kalev suggest, are an effective way to promote social accountability within the organization. Their role is typically to review the diversity numbers in the organization and devise solutions:

Task forces are the trifecta of diversity programs. In addition to promoting accountability, they engage members who might have previously been cool to diversity projects and increase contact with among women, minorities, and white men who participate. They pay off, too: On average, companies that put in diversity task forces see $9 \%$ to $30 \%$ increase in the representation of white women and of each minority group in management over the next five years. ${ }^{169}$

Large Canadian law firms have established diversity committees and from the public statements made by the firms, these committees seem to have a broad mandate to impact both culture and strategy in the firm. In terms of workplace policies, their main focus has been the improvement of employee benefits and programs such as same-sex health benefits, parental leave and access to child and parental care. ${ }^{170}$ These committees may have access to diversity numbers but they typically do not make them available within the firm or to the public. They also do not have stated targets for improving the number of underrepresented groups, although some firms have partial data or targets with respect to the

167 Dobbin \& Kalev, supra note 162.

168 Ibid.

169 Ibid. While the authors' focus is the advancement of women and racialized employees, the same would apply to sexual minorities as another underrepresented group.

170 See e.g. Stikeman Elliot LLP, <http://www.stikeman.com/cps/rde/xchg/se-en/hs.xsl/12244.htm>; Osler, Hoskin \& Harcourt LLP, <https:/www.osler.com/en/why-osler/diversity-drives-better-solutions>; Fasken Martineau LLP, $<$ http://www.fasken.com/diversity/>; Blake, Cassels \& Graydon LLP,

$<$ http://www.blakes.com/English/WhoWeAre/DiversityAndInclusion/Pages/default.aspx $>$. 
representation of women. ${ }^{171}$ The new reporting rules adopted by the LSUC could have significant impact on the work of these committees. A diversity index where the diversity numbers of each firm are made public would increase the accountability of such committees both within the firm and more broadly in the legal services market.

\section{E. Organizational Changes}

The literature on diversity programs suggests, then, that isolated initiatives or remedial measures are not likely to make the workplace more diverse or inclusive. What this scholarship offers as effective strategies to addressing the diversity gap, in turn, are based on findings that are more relevant to the corporate context than to the unique structure of law firms as limited liability partnerships.

Our interview findings help illuminate the day-to-day realities of large law firms given their unique structure. First, the subjectivities of the hiring process can work to exclude members of certain identity groups. While firms have introduced some version of deliberate recruitment targeting underrepresented groups by pairing gay candidates with gay interviewers, lawyers who may choose not to highlight this aspect of their identity on paper could be negatively impacted. Their entry into the firm would depend on how well they connect with the interviewers assigned to assess them, on a personal level. Their success would depend on the biased evaluation of their 'fit.'

Second, and most relevant to the uniqueness of law firms' organizational structure, is the compounding effect of intersectionality on the 'otherness' experience of lawyers. It suggests that often, the diversity gap may be more about race and class than sexual identity. White gay males are more likely to connect with influential figures in the firm, develop meaningful mentoring relationships, and receive important work assignments that help them along the track to partnership. The social capital they already possess upon entering the firm is often more substantial than that of (gay) racialized lawyers. We agree with Wald, who argues that the commodification of lawyers' identity capital ought to be reciprocated by law firms by making the capital exchange more explicit and transparent. This could be achieved by measuring associates' success relative to their capital endowments, and making efforts to ensure that they have an equal opportunity to advance in the firm as their male, white, heterosexual counterparts.

Wald's proposal could be the first step toward leveling the playing field, but it requires a significant departure from the way most big firms are run today. In our interviews, we heard of one example of a firm where the 'origination credits' rule as a basis for compensation was abandoned in favour of a more substantive assessment of lawyers' contribution to the firm. This business model has the potential to address the diversity gap by rewarding excellent work rather than favouring lawyers who happen to be endowed with more social capital than others. In an organization where what you know matters more than who you know, the advancement opportunities for underrepresented groups in the firm could be significantly improved.

The third insight our interviews revealed qualifies the second by considering the impact of organizational structure on the firm's culture. Sexual identity may be a 'non-issue' for lawyers of any racial background as long as they conform to the imperatives of the heteronormative culture of the firm.

171 For example, Osler's data on the representation of women in the firm was made available in their Diversity at Osler: 2016 Year in Review (2016) at 17, online: <https://www.osler.com/osler/media/Osler/reports/corporategovernance/Diversity-in-the-workplace-Osler-2016.pdf $>$. See also Norton Rose Fulbright's commitment to reach $30 \%$ representation of women in partnership (currently $24 \%$ ) by 2020 , online:

$<$ http://www.nortonrosefulbright.com/ca/en/about-us/diversity-and-inclusion/>. Other firms make more obscure statements on women, see e.g. Stikeman Elliott, online: $<$ http://www.stikeman.com/cps/rde/xchg/seen $/ \mathrm{hs} . x \mathrm{sl} / 12249 . \mathrm{htm}>$ ("Our percentage of women equity partners remains well above average among other national law firms"). 
In other words, when it comes to sexual identity, you may be allowed to be different in the firm, but you may not be allowed to act different. The inclusive workplace that many law firms claim to be, therefore, is a place where you must pass into 'normality' by toning down behaviour that does not conform to hypermasculine standards, having a life partner, and assuming the heteronormative roles of men at the firm by working long hours and being available to the firm and its clients around the clock.

The heteronormative culture of the firm and its organizational structure feed off each other, of course, and their impact on women has been studied and documented. In their longitudinal study of Ontario lawyers, Kay, Alarie and Adjei found that women leave practice at higher rates than men and that " $[\mathrm{t}]$ hese departures appear to be largely the consequence of organizational structure and a practice culture that remain resistant to flexible schedules, time gaps between jobs and other leaves." ${ }^{172}$ It was previously assumed that women choose to leave practice because they prefer to focus on family responsibilities and stay home with their children. This view, the authors rightly argue, places the blame on women and overlooks the fact that individual choices are often bound by the workplace's structure and culture. ${ }^{173}$ Their study showed that workplaces offering flexible schedules, for example, significantly improve retention of lawyers. ${ }^{174}$ Gay and lesbian lawyers, we heard from participants in our study, may paradoxically stand to gain in such a culture, as long as they assume the heteronormative male role in their family and submit to the 'around the clock' service mentality plaguing law firms today.

To conclude this part, big law firms have been addressing the diversity gap in several ways, including targeted recruitment efforts, mandating diversity training, establishing diversity committees with a broad mandate but a narrow focus on socialization, and advancement of changes to workplace benefit policies. These initiatives, we argue, are not likely to significantly shift the needle unless they are part of an integrated effort to re-examine the underlying organizational structures that constrain the progress of underrepresented groups. Targeted recruitment that operates in a largely subjective hiring process will continue to result in biased selection. Mentoring obligations that are not transparently and substantially rewarded may result in superficial relationships that make little difference to a junior lawyer's career. And while diversity committees and affinity groups fill an important role in creating an inclusive work environment, they will not have a real impact on the diversity gap unless they are charged with setting clear, measurable objectives with support from the top.

\section{CONCLUSION: FROM INSTRUMENTAL TO SUBSTANTIVE DIVERSITY}

We suggested in the introduction that the approach to address the diversity gap taken by big law firms so far may be termed the 'instrumentalization of diversity,' in the sense that it is a means to another end. The social and legal landscape in Canada and the growing pressure from institutional clients has driven firms to engage in efforts and initiatives that aim to appease their relevant audiences. They have done so at a relatively small cost and without revisiting the organizational structures that arguably produce inequities within the firm. A private practice that is founded on an ethos of excellence but confuses merit with social capital will likely continue to place emphasis on client 'ownership,' on billable hours as the ultimate bottom line, and on workplace policies that favour white, able-bodied heterosexual males.

172 Fiona M Kay, Stacey Alarie \& Jones Adjei, Leaving Law and Barriers to Re-entry: A Study of Departures from and Reentry to Private Practice (A Report to the Law Society of Upper Canada, April 2013) at iii, online:

$<$ http://www.lsuc.on.ca/WorkArea/DownloadAsset.aspx?id=2147494539>. In the U.S. see e.g., Fiona Kay \& Elizabeth Gorman, "Women in the Legal Profession" (2008) 4 Ann Rev L \& Social Science 299.

173 Kay, Alarie \& Adjei, supra note 172 at 7-10.

174 Ibid at 34. 
What could accelerate the required shift from instrumental to substantive diversity? What would bring big law firms to consider meaningful organizational changes that address diversity issues? Participants in our study were convinced that only market imperatives and increased pressure from big clients will make a difference. ${ }^{175}$ The in-house counsel initiative Legal Leaders for Diversity [LLD] we discussed above has the potential to drive this change. The network they formed is focused on their commitment to promote diversity within their own organizations, but also 'encourage' law firms to follow their lead. ${ }^{176}$ The approach they take is markedly different from its American counterpart, originally named "Call to Action" and its Canadian equivalent "Call to Action Canada." 177 The latter group of Canadian in-house counsel is a smaller one and following the American example, the language it employs is far more assertive, placing the conditioning of legal procurement on demonstrated diversification front and centre. ${ }^{178}$ It has received less traction among in-house counsel and it currently includes 11 signatories, ${ }^{179}$ while LLD includes 98.

The soft approach taken by these 98 companies through their legal counsel may change, however, once a law firm diversity index is available. If the data it will provide shows the demographic composition of each firm, including the representation of different identity groups in its leadership ranks, clients would be able to rely on them when deciding where to direct their business. The qualitative reporting big firms share today selectively highlights their initiatives to enhance diversity, without any measures of success. This approach will only go so far in demonstrating their commitment to diversity under the new regulatory regime. Transparency activates social accountability, not only within the firm but also more broadly in the legal services market and the public at large.

175 R1, pp 4-5; R2, p 16; R3, p 15; R4, pp 17-18; R5, p 11; R6, pp 14, 16-17; R9, p 18; R11, pp 4-5; R14, pp 9, 14.

176 Supra note 59.

177 For a discussion of the genesis of both see Chow, supra note 1.

178 See A Call to Action Canada: Diversity in the Legal Profession, online: <http://www.acalltoactioncanada.com/>.

179 See online: $<$ http://www.acalltoactioncanada.com/signatories/>. 